\title{
EL COMPORTAMIENTO DEL PRECIO DEL TRIGO EN GUADALAJARA: INFLUENCIA DEL PÓSITO (1547-1632)
}

por

\author{
ÁNGEL MEJÍA ASENSIO \\ Doctor en Historia Moderna, UNED
}

RESUMEN: La sociedad castellana, supeditada al trigo como principal fuente de alimento, vio cómo a lo largo de la Edad Moderna se fueron repitiendo de forma sistemática diversas crisis de subsistencias que bicieron peligrar el abastecimiento de las ciudades. En este artículo queremos reflejar cómo evolucionó el precio del trigo en Guadalajara a lo largo de un período de casi cien años (1547-1632), desde nuestro punto de vista, los más críticos en la Hacienda castellana, ya que en esos momentos se está experimentando una profunda revolución en los precios en Castila, lo que se vio reflejado en el precio del trigo. Son años en los que la normativa real va dirigida a eliminar en lo posible la causa que provocaba el excesivo precio que estaba adquiriendo este producto en el mercado y que consideraban que era obra de los acaparadores y rentistas; al mismo tiempo que imponían una tasa tras otra, con el fin de alcanzar el objetivo propuesto. Sin embargo, será la actuación del pósito, en este caso el de Guadalajara, el que modere este precio a través de los repartimientos realizados con el trigo almacenado en sus graneros; aunque, bien es cierto, que en otras ocasiones será el principal agente provocador de una subida en este precio en tiempo de normalidad cerealística.

Palabras Clave: Guadalajara. Trigo. Precios. Hacienda. Inflación.

ABSTRACT: Castilian society, living under conditions in which wheat was the main source of food, witnessed a series of subsistences crisis in the course of the Modern Age, endangering supplies to the big cities. This article aims to show bow the fluctuations in the price of the wheat in Guadalajara over a period of almost one bundred years (1547-1632), in our view the most critical years for the Castilian treasury in that prices were experiencing a profound revolution, reflected in the price of wheat. These were years in which the royal regulation was directed to eliminate as much as possible the causes of the high price that this product was reaching in the market, which was considered to be generated by boarding and commercial moneylending. At the same time, they imposed tax after tax in pursuit the proposed objective. Nevertheless, it was the action of the public granary, in this case that of 
Guadalajara, that succeeded in lowering prices through the redistribution of wheat; although it is true that on other occasions it caused inflation of wheat prices during times of regular cereal production.

KEY WORDS: Guadalajara. Wheat. Prices. Public Finance. Inflation.

\section{Problemática y TRATamiento de los datos}

Desde que Hamilton ${ }^{1}$ analizara de forma sistemática los precios de diferentes productos destacando la importancia que la llegada del oro y la plata tuvieron en la revolución de los precios en España, muchos han sido los que se han decidido después a estudiar esta evolución tomando como punto de partida los precios bien desde un punto de vista general de España ${ }^{2}$ bien desde determinadas latitudes españolas, como los estudios realizados sobre Valencia ${ }^{3}$, Navarra ${ }^{4}$, Cataluña ${ }^{5}$ o Andalucía ${ }^{6}$ aportando con sus investigaciones un conocimiento más preciso sobre la evolución de los precios durante la Edad Moderna. Es este segundo caso el que nosotros vamos a tomar como referencia a la hora de llevar a cabo el estudio evolutivo del precio del trigo en un espacio concreto, la ciudad de Guadalajara, y en una época determinada, 1547-1632, que coincide con el período que va entre la fundación de su pósito y su posterior desaparición y todo lo que ello conlleva de influencia en el precio de este cereal.

Nuestras series sobre los precios del trigo de la ciudad de Guadalajara parten, de entrada, de un importante déficit de partida, como es la ausencia de mercuriales al estilo de las existentes en París, Valencia o en Navarra, que fueron defendidas como la principal fuente de información para la elaboración de estos listados por historiadores del prestigio de Ernest Labrousse ${ }^{7}$, para Francia,

\footnotetext{
1 Hamilton, Earl J.: El tesoro Americano y la revolución de los precios en España, 1501-1650, Barcelona, Ariel, 1983. Y de este mismo autor: Guerra y precios en España, 1651-1800, Madrid, 1988.

2 NADAL, Jordi: «La revolución de los precios españoles en el siglo los siglos XVI y XVII: estudio comparativo», en Revista de Historia Económica (Madrid), Año X, otoño, nº 3 (1992), pp.359-395.

3 PALOP RAMOS, José Miguel: «Precios del trigo en Valencia durante el siglo XVIII», en Hispania (Madrid) 5 (1975). De este mismo autor: Fluctuaciones de precios y abastecimiento en la Valencia del siglo XVIII, Valencia, 1977.

4 ARIZCUM CELA, Alejandro: «Series navarras de precios de cereales, 1589-1841», en Estudios de Historia Económica (Madrid) 18 (1989), + 110 págs.

5 VILAR, Pierre: Cataluña en la España Moderna. Investigaciones sobre los fundamentos económicos de las estructuras nacionales, 3 vols., Barcelona, 1987. FELIU, Gaspar. «Precios y salarios en la Cataluña Moderna», en Estudios de Historia Económica (Madrid) 21 (1991). MUÑOz PRADAS, Francisco: «Fluctuaciones de precios y dinámica demográfica en Cataluña (1600-1850)», en Revista de Historia Económica (Madrid) 3 año XV; otoño-invierno (1997), pp.507-544.

6 PONSOT, P.: Atlas de Historia Económica de la Baja Andalucía (siglos XVI al XIX), Sevilla, 1986.

7 LABROUSSE, Ernest: Esquisse du mouvement des prix et des revenus en France au XVIII siècle, París, 1933.
}

Hispania, LXIII/3, núm. 215 (2003) 863-906 
y por Gonzalo Anes ${ }^{8}$, para España; tampoco contamos con los suficientes libros de cuentas del pósito ni de listados de precios en el Concejo en el que basarnos a la hora de hacer una serie fidedigna de esta evolución y que cuenta como su principal defensor con E.J. Hamilton. A pesar de todas estas deficiencias hemos elaborado una serie de precios nominales del trigo bastante completa de casi cien años partiendo para su elaboración de las fuentes disponibles: lo que queda de los libros de cuentas del pósito, los libros de acuerdos del Concejo, los protocolos notariales y algunos libros de fábrica de las antiguas parroquias de Guadalajara, que nos han permitido comprobar que las series elaboradas por Hamilton para Castilla la Nueva difieren muy poco con las que nosotros hemos realizado, lo que nos da idea de la gran labor llevada a cabo por este historiador, quien a pesar de los años transcurridos desde que elaboró éstas sigue siendo el principal y más válido referente en todo lo concerniente a precios en Castilla.

Por otra parte, nuestra pretensión a través de estos listados ha sido la de acercarnos a un problema de vital importancia para las sociedades del Antiguo Régimen, como fue el de su abastecimiento y la influencia que tuvo el pósito en la evolución del precio del trigo, así como proceder al análisis de un período tan conflictivo, desde el punto de vista económico, en el que las carestías, producto de una serie casi sistemática de crisis agrarias, provocaba que los precios subieran de forma dramática para gran parte de la población que no estaba en condiciones de poder adquirir el trigo que salía al mercado, y donde el pósito va a jugar un papel fundamental dentro de este entramado; unas veces como moderador de estas subidas y, en otras, por el contrario, provocador de un aumento en el precio, en especial en aquellos años en los que acuciado por un excesivo número de fanegas almacenadas, obligaba a los propios vecinos a comprar el trigo y el pan a unos precios superiores a los establecidos por el mercado?. El fin no era otro que el de evitar las excesivas pérdidas que al pósito le podía suponer la imposibilidad de vender el trigo comprado en tiempo de carestía.

La función moderadora del pósito de Guadalajara en la evolución de los precios se hizo más perceptible en los años de carestía ${ }^{10}$, cuando su actuación iba dirigida a poner en el mercado importantes cantidades de trigo, previamente almacenadas en sus graneros, con el fin de mitigar en gran medida la escasez de trigo que la ciudad padecía y, en consecuencia, su desabastecimiento, aunque debemos señalar rápidamente que los precios que en esos momentos imponía el Concejo no siempre estaban al alcance de todos los bolsillos, en especial de aquellos a los que pretendía ayudar, los más pobres.

8 ANES Álvarez, Gonzalo: Las crisis agrarias en la España Moderna, Madrid, 1970, pp. 69-72.

9 Esta situación contradictoria entre la existencia de trigo almacenado en el pósito y la persistencia en los altos precios de este trigo para el consumidor, en un mercado donde los precios tienden a la baja se repitió en otras ciudades como en Córdoba; véase YUN CASALILLA, Bartolomé: Crisis de subsistencias y conflictividad social en Córdoba a principios del siglo XVI, Córdoba, 1980, p. 77.

${ }^{10}$ MEjÍA ASENSIO, Ángel: Pan, trigo y dinero. El pósito de Guadalajara (1547-1753), Guadalajara, 2002, pp. 264-340.

Hispania, LXIII/3, núm. 215 (2003) 863-906 
En segundo lugar, el férreo control establecido por parte del Concejo sobre el precio del trigo en los años de abundancia, con el fin de impedir una pérdida significativa en el valor del trigo almacenado en los graneros del pósito, comprado en tiempo de carestía, nos invita a pensar en la situación contraria; es decir, en los perjuicios recibidos por lo vecinos obligados a comprarlo a un precio muy superior que el que se pagaba en las aldeas de alrededor. Los impedimentos que se ponían eran muchos: prohibición de que entrase trigo de fuera mientras no se vendiese el existente en el pósito; obligación de comprar el trigo y el pan a un precio fijado por la ciudad, sin tener en cuenta el establecido por el mercado; prohibición de que saliesen los vecinos a comprarlo a las aldeas; etc.

El análisis del precio del trigo no parte, tampoco, de la influencia que la llegada de metales produjo en la evolución general de precios, aun reconociendo su importancia, que se dejó sentir en la evolución de la moneda castellana desde finales del siglo XVI y principios del XVII. Nosotros partimos del predominio que tuvo el pósito en la evolución de los precios únicamente del trigo y del pan, evolución que vendrá determinada por la actuación del pósito, primero, en los años de carestía y, segundo, durante los años de abundancia. En realidad, se trata más de un intento de hacer más accesibles los períodos de las grandes carestías, que generalmente coinciden con la del aumento de los precios, que de hacer una relación pormenorizada de éstos, aunque a la hora de la verdad éste también se ha realizado.

Por último, y a pesar de todos los inconvenientes citados, quiero dejar constancia de su fiabilidad ${ }^{11}$, ya que si bien a la hora de confeccionar estas series no hemos contado con las posibilidades que ofrecían las mercuriales de las que contaban otras ciudades y a pesar de la influencia que en éstas se observa de los precios ofrecidos por los libros de cuentas del pósito, a los que Palop restaba importancia porque compraban el trigo en tiempo de bonanza, cuando se recogía la cosecha ${ }^{12}$, no es menos cierto que la influencia del pósito de Guadalajara sobre el resto del trigo en el mercado fue determinante en la evolución de los precios, pues el Concejo estuvo siempre pendiente de que el trigo de éste no se perdiese a causa de las diferentes «enfermedades» que su almacenamiento le producía ni que el exceso de una buena cosecha impidiese su venta. Este control del Concejo nos permite reafirmarnos en su fiabilidad. Los medios que se tomaban consistían en la prohibición sistemática de la entrada de trigo más barato en la ciudad mientras no se vendiese el trigo del pósito. De esta manera, los vecinos no se beneficiaron en esos años de abundancia cerealística, pero tampoco sintieron en exceso la falta de trigo durante los años de normalidad, aunque sí lo harían durante los años de carestía, más por los efectos negativos

" Podríamos decir, siguiendo a Cardoso y Pérez Brignoli, que nuestras series se han basado en la mayor confiabilidad, continuidad y homogeneidad posibles a partir de los datos que disponíamos. CARDOSO, Ciro F.S. y PÉrez BRIGNOLI, Héctor: Los métodos de la bistoria, Barcelona, 1984, p. 230.

12 Palop Ramos, José Miguel: Fluctuaciones de precios y abastecimiento en la Valencia del siglo XVIII, Valencia, 1977, p. 11.

Hispania, LXIII/3, núm. 215 (2003) 863-906 
derivados de los acaparadores que por la acción del pósito, que en la mayoría de las ocasiones se veía imposibilitado para luchar contra éstos.

En cuanto a las características del trigo comprado hemos de añadir que las fuentes documentales examinadas apenas si nos informan de ellas. Sabemos, por ejemplo, que el trigo de La Mancha era de mejor calidad porque daba mayor número de panes por fanega que el comprado en Tierra de Campos, la Raya de Aragón o en la Tierra de Guadalajara; asimismo, esta diferencia de calidad se observa dentro de las dos comarcas en que se dividía la Tierra de Guadalajara el trigo de El Campo era mejor que el trigo de La Alcarria vendiéndose el primero, por término medio, dos reales por fanega más caro que el segundo. Pero estas características no se recogen normalmente y sólo nos informan de los precios de origen más los portes, de ahí que sea muy difícil hacer una distinción por calidades.

Otro de los aspectos que se han tenido en cuenta ha sido el determinar la influencia de la población en todo este proceso y hemos de apresurarnos a indicar que, aunque no repercutió de una manera directa en el precio del trigo en todo el período que analizamos, se produce un hecho ciertamente significativo: comprobar cómo la evolución de la población de Guadalajara fue pareja a la del propio pósito, coincidiendo en los años de mayor población con una mayor incidencia de éste sobre la ciudad; y, asimismo, en los años en los que el pósito perdió peso específico en el abastecimiento de ésta coincide con los años en los que la población había disminuido notablemente, tras la peste de 1599 y la posterior marcha de los duques del Infantado a Madrid, a principios del siglo XVII, dejando una población arruinada y sin medios con los que enfrentarse a un período tan crítico como era el que se avecinaba. La población de Guadalajara se movía en torno a los 8000 a 9000 habitantes a finales del siglo XVI'13, fechas en las que el pósito almacenaba en sus graneros cantidades próximas o superiores a las 15000 fanegas de trigo (ver cuadro X), suficientes para atender a esa población en caso de necesidad, como así ocurrió con frecuencia en la última década del siglo. Tras la marcha de los duques y la expulsión de los moriscos de la ciudad, en 1610, la población disminuyó notablemente, hasta los 4980 habitantes, según Manuel Rubio Fuentes, que se tradujo en una menor cantidad de trigo almacenado. Sin embargo, en los años siguientes, y según se desprende de la bula de la santa cruzada de 1618, la población debió de subir hasta los 6300 habitantes ${ }^{14}$ y que coincidió con un incremento del trigo almacenado en el pósito, cifrado en los años anteriores a esta fecha en unas 11000

13 Sobre la evolución de la población en Guadalajara ver RUBIO FUENTES, Manuel: «Evolución demográfica de Guadalajara durante los siglos XVI y XVII», en Wad-Al-Hayara, n 25 , Guadalajara, 1998 , p. 110.

14 MEjía AsENSIO, Ángel: «La bula de la santa cruzada de 1618. Aproximación a la estructura socioeconómica de la ciudad de Guadalajara a principios del s. XVII», en Iglesia religiosidad en España. Historia y Archivos, Volumen I, en Cuadernos de Archivos y Bibliotecas de Castilla y La Mancha. 7, Guadalajara 2002, pp. 73-108.

Hispania, LXIII/3, núm. 215 (2003) 863-906 
fanegas (ver cuadro XVI). A partir de entonces la actividad del pósito se vio muy reducida, coincidiendo con la propia decadencia de la ciudad, que vio cómo su población se reducía hasta los 3936 habitantes en $1643^{15}$, cuando el pósito ya había desaparecido.

Anotar, finalmente, que una vez recopilados los precios se nos planteó el problema relativo a su tratamiento, si íbamos a comenzar a principios del año o si lo iniciábamos con la fecha de elección del mayordomo, el 26 de julio. Después de sopesar los pros y contras decidimos que lo mejor era comenzar con el año, ya que la elección de mayordomo, con el paso del tiempo se llevó a cabo en fechas distintas y tampoco nos iba a resolver el problema si lo hacíamos partiendo desde su fecha de elección. Al mismo tiempo se simplificaba bastante la elaboración de estas series. En un primer momento se pensó en hacerlas mensuales o al menos trimestrales, pero la dificultad de encontrar precios en cada trimestre, no digo ya en cada mes, fueron enormes, por lo que se tuvo que desechar esta idea. En otras ocasiones los problemas se relacionaban con la falta de precios o a que sólo se mencionase el pago del trigo a la tasa. Otras veces al precio de la tasa se añadían los portes y portazgos, con lo que el precio final era mucho mayor; u ocurría todo lo contrario, no se mencionaban los pagos de portes y portazgos, aunque por los precios que aparecían se veía claramente que ya iban incluidos; en otros, en fin, se añadían además los salarios, sin que sepamos el precio inicial del trigo. Con todo estos condicionantes sólo queremos dejar constancia de la dificultad que supone establecer una serie a partir de estas fuentes, ya que la información de la que disponemos no es todo lo homogénea que hubiésemos deseado. No obstante, se han intentado corregir en lo posible los precios extremos de cada año mediante la realización de unas medias aritméticas y teniendo en cuenta los procedimientos derivados de las medias móviles, el cálculo de los números índices, el movimiento de larga duración o las desviaciones cíclicas, procurando evitar en lo posible las posibles tergiversaciones producidas por un baile de precios de un año en concreto o las deformaciones que se pudiesen derivar en los movimientos cíclicos.

\section{INCIDENCIA DE LA TASA EN EL PRECIO DEL TRIGO.}

El precio del trigo, hasta la Real Pragmática del 11 de julio de 1765, en que se suprimió, estuvo sujeto a una serie de controles por parte de la corona, con la pretensión de fijar el precio máximo de éste, ante los continuos problemas de abastecimiento provocados por los acumuladores y acaparadores, dedicados a retirar de forma sistemática el trigo de la venta, perjudicando a la generalidad de la población de Castilla. Esta regulación se conoció con el nombre

is RUBio FuENTES, Manuel: "Evolución demográfica de Guadalajara durante los siglos XVI y XVIl», en Wad-Al-Hayara, n 25, Guadalajara, 1998, p. 110.

Hispania, LXIII/3, núm. 215 (2003) 863-906 
de tasa y ha sido objeto de numerosos estudios con el fin de conocer con mejor precisión el problema de los precios de Castilla, especialmente desde que Hamilton incidiera en ello ${ }^{16}$. Nuestra intención no es volver a hacer un estudio sobre la importancia de la tasa en la economía castellana, sino una somera aproximación a la influencia que tuvo en la evolución de los precios de compra del trigo del pósito de Guadalajara y cómo incidió en la ciudad.

En teoría el precio del trigo y el de otros cereales como la cebada y el centeno se determinaban por la tasa, especialmente en los años de carestía, sin embargo, en aquellos años en los que la cosecha se podía considerar como normal o buena, ésta apenas si se tenía en cuenta, sólo la guardaban los eclesiásticos ${ }^{17}$, siendo regulados los mecanismos de compra por el propio Concejo, aunque no siempre, según Brumont, podía evitar la especulación ${ }^{18}$. En este sentido debemos añadir que en ocasiones la propia noticia de una nueva tasa producía los efectos contrarios debido a la retirada del mercado de grandes cantidades de cereal por parte de los acaparadores (rentistas, dezmeros, titulares de censos), que era contra quienes en teoría se utilizaba ésta, provocando una escasez artificial $^{19}$ y el consiguiente encarecimiento del trigo. Estos contrataban la mayor parte del trigo que se comerciaba, comprándolo a los pequeños labradores en los meses que van de agosto a octubre a muy bajo precio. Estas ventas, realizadas generalmente en las eras, fueron prohibidas en las Cortes de 1523, 1528 y 1548, con el fin de evitar el endeudamiento de los labradores, al mismo tiempo que adoptaban otra serie de medidas como el de obligarles a vender el trigo en la cilla o en la alhóndiga ${ }^{20}$.

A pesar de estos intentos los acaparadores siguieron retirando del mercado grandes cantidades de trigo, que guardaban en sus cámaras, en espera de que los precios subieran, fruto de la escasez por ellos provocada. Cuando esto sucedía era el momento de sacar de sus graneros el trigo acopiado, obteniendo un gran beneficio de su venta, máxime si tenemos en cuenta los meses en los que se vendía: abril, mayo y junio. Esta forma de actuar tuvo como principales opositores a los propios monarcas quienes persiguieron estas actuaciones irregula-

16 HAMilton, Earl J: El tesoro americano y la revolución de los precios en España, 1501-1650, Barcelona, 1983, pp. 257-276. Otros historiadores que han estudiado esta tasa con un carácter general son CASTRO, Concepción de: El pan de Madrid. El abasto de las ciudades españolas del Antiguo Régimen, Madrid, 1987, pp. 69-86.

17 Domínguez Ortiz, Antonio: El Antiguo Régimen: Los Reyes Católicos y los Austrias, Madrid, 1986, p. 157. LÓPEZ-SALAZAR, Jerónimo y MARTín GALÁN, Manuel: «La producción cerealística en el arzobispado de Toledo. 1463-1699", en Cuadernos de Historia Moderna y Contemporánea. (Madrid) Volumen II, (1981), p. 27.

18 BRumont, Francis: Campo y campesinos de Castilla la Vieja en tiempos de Felipe II, Madrid, 1984 , p. 38.

19 Gelabert GonZÁlez, Juan Eloy: Santiago y la Tierra de Santiago de 1500 a 1640, La Coruก̃a, 1982, p. 214.

20 CARAnde, Ramón: Carlos $V$ y sus banqueros. 1. La vida económica en Castilla, $4^{\mathrm{a}}$ edic., Barcelona, 1990, pp. 127-134.

Hispania, LXIII/3, núm. 215 (2003) 863-906 
res a través de una amplia legislación, en la que les acusaban de provocar la miseria y el hambre en el pueblo, hecho que se repitió de forma sistemática a lo largo de todo el siglo XVI.

En cuanto al pósito eran las propias ordenanzas las que regulaban la compra y venta de trigo, en especial, en el tema concerniente a cuándo era el momento propicio para comprar, que estaba establecido que fuese en los meses en los que se recogía la cosecha, por su bajo precio; así como la fecha en la que se debía vender, que se fijó en los meses mayores, cuando los precios eran más altos. Estas variaciones del precio atendiendo a los cambios estacionales se venía repitiendo con relativa normalidad en otras ciudades castellanas como en Valladolid $^{21}$. Cuando el trigo no se compraba en su jurisdicción sino en lugares más alejados, a causa generalmente de una crisis de subsistencias en la zona, los precios que se pagaban estaban limitados por la tasa, lo mismo que les ocurría, por ejemplo, a los mercaderes locales que vendían en la plaza. A este precio habría que añadir un sobreprecio procedente de los portes, salarios, etc., que encarecía en exceso el producto. El pósito en estas ocasiones y ante la necesidad de abastecimiento de sus vecinos se veía obligado a entregar este trigo a un precio menor del que pagó, con las correspondientes pérdidas para sus arcas. En definitiva, el pósito era considerado en cualquiera de las situaciones como un comprador más, estando obligado a pagar al precio de tasa, aunque en ocasiones ni aún pagando la tasa se encontraba trigo ${ }^{22}$.

El origen oficial de la imposición de un precio máximo para el trigo y otros cereales lleva fecha de 23 de diciembre de 1502 cuando los Reyes Católicos decidieron que su precio máximo fuera de 110 maravedíes la fanega de trigo; asimismo, se fijó el precio de la cebada, que quedó en 60 maravedíes y el del centeno, en 70 . Se pretendía, de esta forma, impedir que muchos campesinos, agobiados por las deudas, vendiesen sus tierras para poder mantener a sus familias $^{23}$. El período de vigencia de esta tasa se fijó en diez años.

Hubo que esperar, sin embargo, casi treinta años para que se promulgase una nueva tasa, fechada el 10 de octubre de 1539. Esta separación en el tiempo entre una y otra no la podemos achacar a un desinterés real pues Carlos I ya venía elaborando un nuevo proyecto de tasa desde unos años antes, según se desprende de una carta mandada a los alcaldes ordinarios del Concejo de Guadalajara el 10 de enero de $1531^{24}$ solicitando la opinión de sus regidores y personas experimentadas sobre la conveniencia o no de poner tasa para frenar el

21 BENNASSAR, Bartolomé: Valladolid en el siglo de oro. Una ciudad de Castilla y su entorno agrario en l siglo XVI, Valladolid, 1989, pp. 258-260.

22 En Córdoba se quejaban en 1597 de que no se encontraba trigo ni al precio de la tasa. ForTEA PÉREZ, José Ignacio: Córdoba en el siglo XVI: las bases demográficas y económicas de una expansión urbana, Córdoba, 1980, p. 215.

23 HaMiLTON, Earl J.: El tesoro americano y la revolución de los precios en España, 1501-1650, Barcelona, 1983, p. 258.

24 Archivo Municipal de Guadalajara (AMGU)*. Leg. 1H4.001.

Hispania, LXIII/3, núm. 215 (2003) 863-906 
alto precio que estaban alcanzando el trigo, la cebada y el centeno y para que fijasen el precio que considerasen más justo. De esta manera, intentaba implicar al Concejo en una situación que era muy controvertida, máxime si además, como ocurrió en este caso, se les aconsejaba-obligaba a que pusiesen un precio máximo de venta al trigo que se vendiese en la ciudad en tanto que se decidía el precio más conveniente para la nueva tasa, sin que nadie pudiese venderlo más caro.

Este interés queda patente, de nuevo en 1536; en esta ocasión Carlos I, conocidos los problemas de abastecimiento que estaba sufriendo la población a causa de los acaparadores, se dirigió, a través de una Real Provisión ${ }^{25}$, a los concejos de Guadalajara, Tendilla y otros lugares, para que se informasen sobre aquellos que se dedicaban a acaparar el trigo para luego revenderlo, autorizándoles a que tomasen del trigo que tuviesen almacenado la cantidad que les pareciere más conveniente para el abastecimiento de la ciudad, vendiéndolo a un precio moderado y tenierído en cuenta el precio a que fue comprado y las costas ocasionadas. Aunque desconocemos la contestación del Concejo alcarreño, nos puede servir de ayuda la respuesta dada por su homólogo de Córdoba quien contestó que se vendiese el trigo y la cebada a siete y cuatro reales respectivamen$t^{26}$, aunque poco después pidieron que la aplicación de la tasa se suspendiera temporalmente para no dificultar la traída de trigo a Córdoba.

La nueva tasa quedó establecida, finalmente, el 10 de octubre de 1539, para el reino de Toledo, en 170 maravedíes la fanega de trigo; 85 maravedíes la fanega de cebada; y en 114 maravedíes, la fanega de centeno, con la salvedad de que éstos eran los precios fijados en los lugares de venta, no en los de consumo, como ocurrió en $1502^{27}$, con lo que el precio final se vio aumentado considerablemente al tener que pagar los portes. Esta tasa no debió de estar en vigor durante mucho tiempo, según se desprende de las opiniones vertidas por el Concejo de Almaguer en $1546^{28}$, en respuesta a una nueva demanda real sobre la conveniencia o no de aplicar la tasa. Estas peticiones a los concejos castellanos fue una constante cada vez que se pretendía revisar la tasa o implantar una nueva. En este caso y ante la falta de las respuestas dadas por la ciudad de Guadalajara, nos serviremos de las aportadas por el Concejo de Almaguer, quien hizo llegar al rey una larga lista de perjuicios e inconvenientes derivados de esta nueva imposición. La respuesta dada por esta villa, sin embargo, tuvo una doble dirección; por una parte, se trató de ver los beneficios que aportaría a la sociedad en general una nueva tasa, llegando a la conclusión de que ésta iba a beneficiar a ricos y a pobres y que serviría para moderar los

\footnotetext{
25 AMGU, Leg. 1H4.001, Madrid, 20 de febrero de 1536

26 FORTEA PÉREZ, José Ignacio: Córdoba en el siglo XVI: las bases demográficas y económicas de una expansión urbana, Córdoba, 1980, p. 213

27 Hamilton, Earl J: El tesoro Americano y la revolución de los precios en España, 1501-1650, Barcelona, 1983, p. 261.

28 Archivo General de Simancas (AGS)*, Diversos de Castilla, Leg. 46, $\mathrm{n}^{\circ} 74,13$ de diciembre de1546.
} 
precios e igualarlos desde Andalucía hasta Burgos; aunque hizo constar que frente al interés general algunos concejos buscaban su propio beneficio. Por otra, establecía Almaguer una segunda vía, recogida en una serie de perjuicios e inconvenientes que una nueva imposición de la tasa iba a proporcionar al reino, añadiendo una serie de consejos que de forma resumida y por su interés enumeramos a continuación:

- Las tercias reales, los arrendadores y regatones y aquellos que tuviesen suficiente trigo para vender, no sufrirían perjuicio alguno, ya que las tercias las tenía el rey encabezadas y los regatones y arrendadores habían comprado ya el trigo a tales precios que no perderían con la nueva tasa. En cuanto al trigo que percibía el rey del perteneciente a los maestrazgos, tampoco recibiría perjuicio siempre que el precio del trigo no bajase de los ocho reales y el de la cebada de los cuatro reales por fanega.

- Ciudades como Sevilla, Toledo, Segovia o Burgos, que se proveían por acarreo no eran partidarias de que hubiese tasa. Por otra parte, aquellas zonas en las que no se pusiese la tasa, éstas tenderían a subir el precio del trigo al tasado, con el fin de obtener un mayor beneficio. Por ello sería bueno generalizar la tasa a todo el reino, menos en Guipúzcoa y Vizcaya, que se abastecían de Francia. El precio que el Concejo de Almaguer estimaba como el más correcto y que proponía al rey era el de nueve reales (306 maravedíes) la fanega de trigo y de cuatro reales y medio (158 maravedíes) el de la cebada; siendo este precio determinado por el rey y no por los concejos.

- Para controlar que no faltase trigo, aconsejaba que se hiciese un registro generalizado en todas las iglesias y monasterios y que si sobraba pan lo pudiese comprar cualquier persona y venderlo fuera de la ciudad, en otros pueblos, al precio de la tasa. Por ello, al existir la tasa, tampoco sería conveniente que se prohibiese la existencia de arrendadores y compradores. Sin embargo, apuntaba la posibilidad de que se prohibiese la saca de trigo a Valencia y a Portugal; en cuanto a Aragón, dice, ya tenía suficiente trigo desde que se construyó la acequia real.

- En referencia a los pósitos señalaban que no se aplicase a ellos la tasa, sino que lo dejase a la libre determinación de los pueblos, mientras que no lo pudiesen vender ni panadear al precio de ésta.

A pesar de estos consejos de la villa de Almaguer, continuaron los problemas con los acaparadores, siendo necesaria la promulgación de una Real Provisión en 1548, tras la celebración de las Cortes en Valladolid, en las que se autorizaba a los concejos a tomar la mitad de las rentas de estos acumuladores para que la ciudad se pudiese proveer de trig $0^{29}$.

\footnotetext{
29 AMGU, Leg. 1H4.001. Valladolid, 2-8-1548.
} 
Tras casi veinte años de vigencia de esta tasa fue necesario hacer una nueva revisión para determinar el precio máximo del trigo; en esta ocasión la tasa se fijó en 310 maravedíes el 9 de marzo de 1558. Previamente a esta imposición Felipe II, al igual que había hecho su padre, pretendió implicar a las ciudades castellanas; con este fin y a través de varias Reales Provisiones se dirigió durante 1557 y los primeros meses de 1558, al Ayuntamiento de Guadalajara, notificándole la necesidad de su aplicación. En estas Provisiones el rey se preguntaba acerca del excesivo precio del trigo cuando la cosecha había sido buena, al mismo tiempo que le pedía opinión a la ciudad sobre el precio al que consideraba conveniente fijar la nueva tasa. Pero al contrario de lo que ocurriera con su padre las preguntas realizadas llevaban implícitas las respuestas pertinentes por lo que debemos considerarlas más como órdenes reales que como una solicitud de opinión. Así aconsejaba que los precios debían ser moderados y que los verdaderos culpables no eran otros, una vez más, que los acaparadores, ya fueran seglares como eclesiásticos, a los que se les obligó a realizar un registro de todo el trigo que tuviesen para ponerlo a la venta, ya que tenían a toda la ciudad desabastecida.

Si en los casos anteriores apenas si disponemos de noticias sobre su cumplimiento en Guadalajara ahora por el contrario son numerosos los documentos en los que se recoge la obligatoriedad de comprar a este precio, entre los que destacamos la autorización que Felipe II realizó en este sentido al Concejo en $1562^{30}$. Previamente, en 1560 , se tomaron medidas tendentes a abastecer de trigo a la ciudad como ya se había hecho con anterioridad, en concreto en 1548 , al permitir la venta de la mitad de las rentas de los más ricos y acaparadores para con ellas abastecer a sus vecinos ${ }^{31}$.

Pero los problemas de abastecimiento no desaparecieron, insistiendo Felipe II que los únicos culpables de esta continua subida de precios eran los acaparadores. Como principal medida tomó una que ya se había puesto en práctica en 1548 , la de prohibir la venta de pan cocido a los que no fueran panaderos, debido a que lo vendían a mayor precio que el estipulado por la tasa ${ }^{32}$. Finalmente, Felipe II tuvo que recurrir, a una nueva revisión al alza; en esta ocasión mediante la promulgación de dos pragmáticas muy seguidas, fechadas el 29 de agosto de 1566 y el 8 de octubre de 1571, reflejando con ello el poco interés que los concejos tenían en llevarla a la práctica. Los precios fijados fueron, para el trigo once reales (374 maravedíes); la cebada medio ducado (187 maravedíes); y el centeno a 200 maravedíes la fanega ${ }^{33}$.

La última revisión al alza de la tasa en el siglo XVI se llevó a efecto el 24 de septiembre de 1582 cuando se puso un precio máximo al trigo de 476 maravedíes. Las causas de esta nueva tasa las resume el propio rey en la «esterilidad de

30 En dicho año el rey autorizaba a vender al pósito al precio determinado por la tasa. AMGU. Leg. 1H4.002, Madrid, 4 de mayo de 1562.

31 AMGU. Leg. 1H4.002. Real Provisión, fechada en Toledo, 13 de mayo de 1560.

32 AMGU. Leg. 1H4.002. Pragmática, fechada en Madrid, 23 de agosto de 1571.

33 Copia de la pragmática de 12 de marzo de 1582, AGS. Diversos de Castilla, Leg. 1, $\mathrm{n}^{\circ} 40$. 
los tiempos», algo muy socorrido en todas las subidas anteriores. Sin embargo, su imposición incidía de forma negativa en la agricultura en general; los labradores se quejaban de que tenían más costos a la hora de labrar la tierra, los salarios eran cada vez más altos y les salía más rentable dejar de labrar las tierras. Este abandono de los cultivos traía consigo la subsiguiente falta de trigo y de pan y con ellos el hambre entre la población.

Los mayores problemas relacionados con su aplicación surgieron a finales del siglo y fueron paralelos a los problemas generales de la agricultura. El abandono de los campos fue motivo de una preocupación especial para el rey, quien se dedicó a investigar acerca de los males que afectaban a los bajos rendimientos agrícolas y al abandono de las tierras, como quedó expuesto en una carta enviada a los concejos castellanos en 1598. Las razones esgrimidas para hallarse en dicha situación fueron varias. En primer lugar, el hecho de que los moriscos no se dedicasen a la agricultura y sí al comercio; los diferentes concejos consultados creían que si se obligaba a los moriscos a ocuparse de las labores agrícolas los precios de la labranza se moderarían y, en consecuencia, bajarían a su vez los precios del vino, carnes y legumbres. Y, en segundo lugar, al excesivo salario de los jornaleros, a los que se les debía imponer una tasa. Como modelo a seguir propusieron que se tuviese en cuenta el precio de la tasa de 1582, que para el trigo creían apropiado que fuese de 476 maravedíes la fanega; para la cebada pidieron que subiera a 272 maravedíes; para la avena, 136 maravedíes; y para el centeno, 306 maravedíes ${ }^{34}$.

Mientras los concejos discutían sobre estas cuestiones el pan no llegaba a los vecinos, a la vez que veían impertérritos cómo en Guadalajara, por ejemplo, el precio del pan forastero subía hasta los 22 maravedíes, cuando su precio estaba en torno a los 14 y 16 . La razón de esta subida se encontraba en la negativa de los labradores a cocer ellos mismos el pan, asustados por la investigación que estaba llevando a cabo el doctor Garontes, desde $1593^{35}$, quien al frente de una comisión estaba investigando a los transgresores de la tasa ${ }^{36}$. La solución que dio el regimiento para evitar este desabastecimiento fue que los vecinos de la ciudad pudiesen vender también el pan a 22 maravedíes o que dejase de investigar el comisionado real. Esta petición fue atendida por Felipe III tras responder a un memorial aprobado por las cortes el 4 de noviembre de 1599 .

Con la llegada del nuevo siglo y una vez superados los problemas que la peste provocó en Castilla, se hizo una nueva revisión al alza de la tasa ante la subida experimentada por el precio del trigo. En esta ocasión, el 2 de septiembre de 1605 , se situó el precio máximo en dieciocho reales (612 maravedíes) la fanega de trigo, y en 306 maravedíes el de la cebada.

\footnotetext{
34 AMGU. Libro de Acuerdos (L.A.)*, 28 de Julio de 1598.

35 HAMILTON, Earl J: El tesoro Americano y la revolución de los precios en España, 1501-1650, Barcelona, 1983, p. 268.

36 AMGU .L.A., 25 de Enero de 1599.

Hispania, LXIII/3, núm. 215 (2003) 863-906
} 
CUADRO I

EVOLUCIÓN DE LA TASA EN MARAVEDÍES, 1502/1699

\begin{tabular}{|l|c|c|c|}
\hline AÑOS & $\begin{array}{c}\text { Precios } \\
\text { del trigo }\end{array}$ & $\begin{array}{c}\text { Precios } \\
\text { de la cebada }\end{array}$ & $\begin{array}{c}\text { Precios } \\
\text { del centeno }\end{array}$ \\
\hline 1502 & 110 & 60 & 70 \\
1539 & 170 & 85 & 114 \\
1558 & 310 & 140 & 200 \\
$1566 / 1571$ & 374 & 187 & 200 \\
1582 & 476 & 204 & 272 \\
1605 & 612 & 306 & \\
1699 & 952 & 442 & 578 \\
\hline
\end{tabular}

La medida fue muy mal recibida por las ciudades, hasta el punto de que en las Cortes celebradas en octubre de 1608 , se votó que el precio máximo del trigo quedase en catorce reales ( 476 maravedíes) y el de la cebada en siete reales (238 maravedíes). En Guadalajara la situación no varió mucho sobre el resto de concejos castellanos. En un primer momento, como ocurrió en 1606, se compró trigo a la tasa establecida ${ }^{37}$; sin embargo, en las reuniones del Concejo a lo largo de 1607, tras la publicación de la Pragmática, surgieron voces discrepantes al respecto, opinando que se debía eliminar la pragmática sobre el pan y sobre todo tipo de semillas; vendiéndose éste a «postura» de la justicia y del regimiento de cada lugar. La actitud general quedó recogida en la opinión del comisario don Pedro de Alarcón, alférez mayor, que se puede resumir de la forma siguiente ${ }^{38}$ :

- La causa de valer tanto el trigo y de no encontrarlo es porque no se siembra, estando la mitad de las tierras labrantías.

- La razón de que no se siembre se debe a la aplicación de la tasa, ya que todo vale caro y los salarios de los criados están muy altos, siendo el único producto que tiene tasa el trigo. Por ello ante los años de malas cosechas (como los años anteriores) le costaba cada fanega al labrador tres o cuatro ducados (1.125 y 1.500 maravedíes, respectivamente), y más al que no era labrador, que todo lo hacía por mano ajena, por lo que al estar tan caro y ver éste que sólo sacaba 18 reales (612 maravedíes), por necio que fuese dejaba de sembrar, labrando sólo para su propio sustento, abandonando, también, las tierras arrendadas. Ante la falta de trigo los demás debían ir a buscarlo fuera de Castilla, donde no había tasa. Es-

37 Luis de Amores pide testimonio al escribano de la villa de Cangas (La Coruña) de que comprara 1.000 fs de trigo a 18 rs la fanega, precio de tasa. AMGU. L.A. 30 de agosto de 1606.

38 AMGU. L.A.18 de julio de 1607. 
tos mismos problemas o parecidos los tuvieron los propietarios y arrendatarios cordobeses quienes a fines de 1599 veían cómo se les castigaba por haber vendido a precio más alto del fijado por la tasa, lo que hizo clamar contra ella al propio cabildo de Córdoba al ver cómo estos labradores perdían sus labranzas ${ }^{39}$.

- Que se quitase la tasa y que el trigo se vendiese a razón de la cosecha, como el vino y el aceite.

- Que el que labrase su trigo lo pudiese también cocer, él o sus criados.

- Que el labrador que no tuviese labradas doce fanegas no gozase de las exenciones de los labradores.

- Que se eliminasen los pósitos, que por su mala administración tenían a los pueblos destruidos. En caso de que éstos siguiesen funcionando pedía que se prohibiese el almacenamiento del trigo para luego venderlo en grano.

- Que los diezmos se paguen y se recojan en las eras.

\section{GRÁFICO I}

EVOLUCIÓN DE LA TASA DE LOS CEREALES EN MARAVEDÍES, 1502/1699

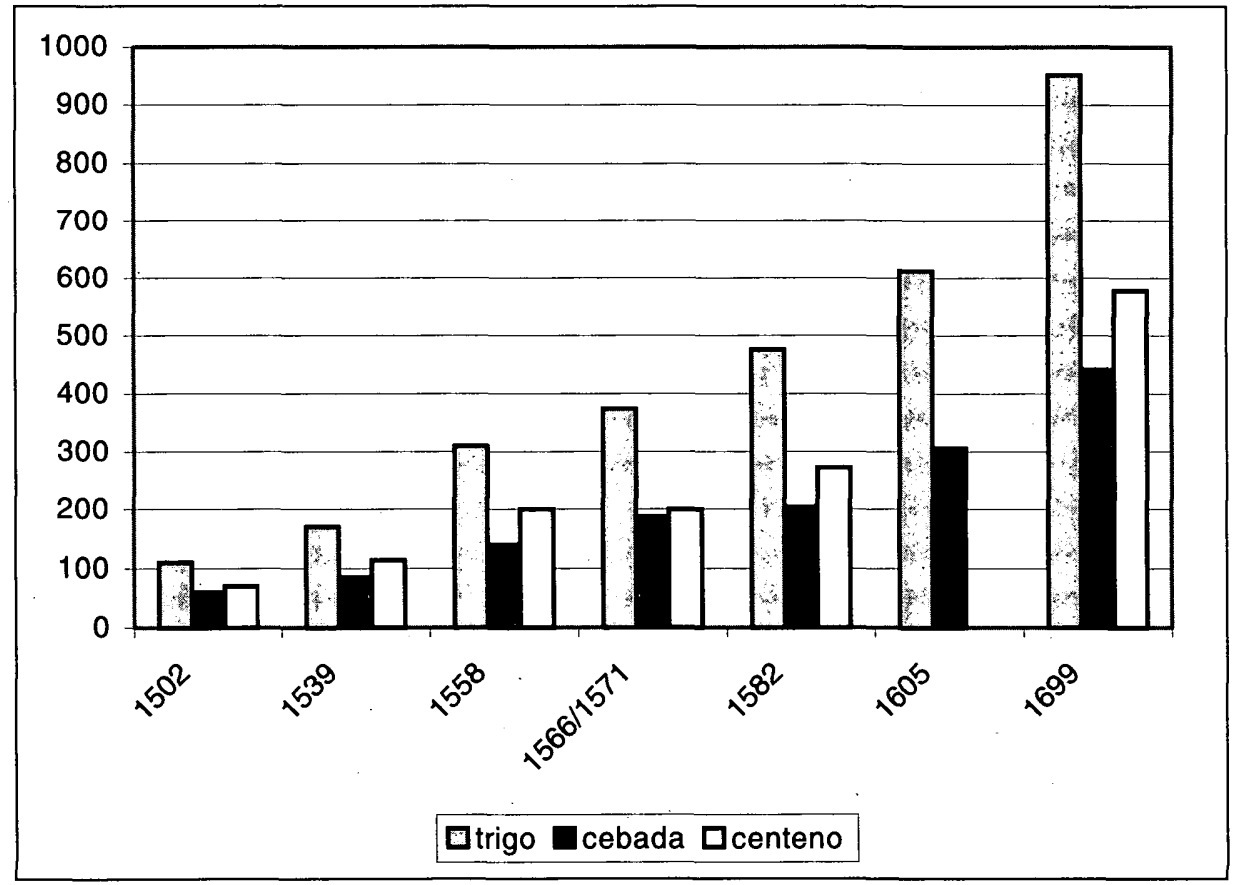

39 FORTEA PÉREZ, José Ignacio: Córdoba en el siglo XVI: las bases demográficas y económicas de una expansión urbana, Córdoba, 1980, p. 213.

Hispania, LXIII/3, núm. 215 (2003) 863-906 
Durante los siglos XVII y XVIII pocas variaciones se produjeron respecto a la tasa, ya que los precios fijados en 1605 fueron confirmados en 1631 ; sin embargo, esta rigidez quedó rota de forma momentánea en 1619 gracias a una merced de Felipe III por la que autorizaba a los labradores a que vendiesen el trigo de su cosecha a un precio superior al de la tasa, al igual que ocurriera en 1584, cuando hubo una cosecha muy corta ${ }^{40}$ : Salvo este pequeño inciso, los precios marcados por la tasa permanecieron vigentes hasta el 14 de agosto de $1699^{41}$, cuando se fijó un nuevo máximo en la fanega de trigo de veintiocho reales; trece reales la fanega de cebada; y diecisiete reales la de centeno. Esta nueva tasa permaneció en teórica vigencia hasta 1765 , fecha en que se decretó la libertad del comercio de granos.

\section{INFLUENCIA DE LOS PORTES EN EL PRECIO DEL TRIGO}

La importancia de contar con unas buenas vías de comunicación con las zonas productoras de trigo para la economía castellana del Antiguo Régimen fue, sin duda, un factor clave en el precio final del trigo. La posibilidad de encontrar este cereal a una distancia prudencial y por unos buenos caminos era un alivio para las ciudades ya que en unos pocos días, y en caso de necesidad, podían desplazarse hasta allí para comprar el grano suficiente con el que mitigar el desabastecimiento de su población. Pero salir a la búsqueda de trigo, aunque sólo fuera hasta los lugares de su jurisdicción, suponía sumar al precio de compra otros conceptos como los salarios, el alquiler de graneros en los lugares de compra, las dietas y, sobre todo, los portes y portazgos que gravaban considerablemente el precio final del trigo.

Por ejemplo, en 1580 Íñigo de Amores compró 1487 fanegas de trigo en Segovia por las que pagó un total de 817.000 maravedíes $^{42}$, en los que se incluían los portes, el precio del trigo y los salarios, es decir, el trigo alcanzó una media de 549 maravedíes. Desglosado por conceptos obtenemos que por las 1487 fanegas compradas a 374 maravedíes la fanega, precio de la tasa, se pagaron 556.138 maravedíes, por lo que el resto, 260.862, corresponde al pago de los otros conceptos señalados, es decir, un incremento de 175 maravedíes por cada fanega, lo que supone un aumento en el precio final de un 68 por ciento. De esta cantidad, el comprador, Íñigo de Amores, se llevó 50568 maravedíes, a razón de 34 maravedíes por fanega comprada, lo que significa el seis por ciento del total, el resto, 210.294 maravedíes correspondió a los portes y los salarios de los demás arrieros. Los precios por legua y fanega transportada ya

40 CARANDE, Ramón: Carlos $V$ y sus banqueros. 1. La vida económica en Castilla, $4^{\mathbf{a}}$ edic., Barcelona, 1990 , p. 130 .

41 Hamilton, Earl J: Guerra y precios en España, 1651-1800, Madrid, 1988, p. 225.

42 AMGU. Leg. 1H41-3. Cuenta tomada el 26 de marzo de 1580 por el escribano de Segovia Francisco de Laredo. 
habían sido fijados por la pragmática de 1558 , dejándolos en seis maravedíes en el caso del trigo y del centeno y de cinco en el de la cebada y avena, y permanecieron en vigor hasta 1582 , fecha ${ }^{43}$ en la que el rey autorizó a que se pudiesen llevar hasta diez maravedíes por fanega transportada del trigo y del centeno y ocho maravedíes por la cebada y avena. Sin embargo, la tónica más generalizada hasta 1632, fue la de cobrar por este concepto cantidades muy diferentes a las establecidas, circunstancia que fue recordada en numerosas ocasiones por la ciudad de Guadalajara a los transportistas, como en $1592^{44}$. La razón esgrimida por los transportistas para aumentar los precios era la incidencia de la propia carestía; o, por el contrario, el hecho de que en los años de abundancia se regulasen por la propia oferta y demanda de cada lugar. A pesar de todo, este incremento fue, según Domínguez Ortiz, menor que el índice general de precios que se registraba a principios del siglo XVII, que fue el doble ${ }^{45}$.

\section{GRÁFICO II \\ PRECIO DE LOS PORTES EN MARAVEDÍES POR LEGUA Y FANEGA, 1579/1621}

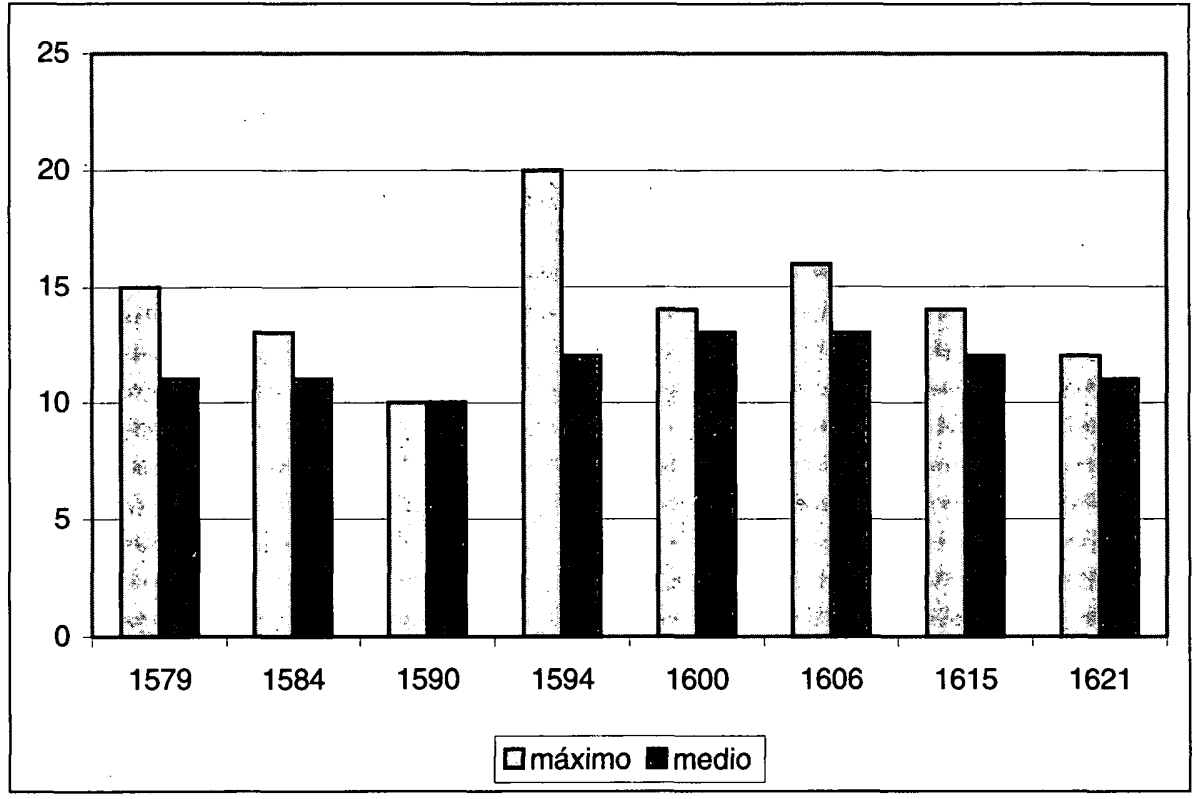

43 AGS. Diversos de Castilla. leg. $1, \mathrm{n}^{\circ}$ 40. Pragmática sobre el aumento y tasa de los precios del trigo. Madrid, 12 de marzo de 1582.

${ }_{44}$ Les remiten al precio de la pragmática. AMGU. Leg. 1H42b-1.

45 Domínguez Ortiz, Antonio. El Antiguo Régimen: Los Reyes Católicos y los Austrias, Madrid, 1986, p. 95.

Hispania, LXIII/3, núm. 215 (2003) 863-906 
El precio de los portes en 1584, por ejemplo, fluctuó entre los mencionados diez maravedíes de la pragmática, pagados por las compras realizadas en agosto en Tierra de Campos o en la cercana Fuentelahiguera; a los once pagados en el mes de septiembre en Tierra de Campos o los trece en el condado de Paredes. Los portes en 1590 fueron también más elevados de lo normal, alcanzando los catorce maravedíes el trigo comprado en Atienza. Pero una vez más, en aquellos pueblos más próximos a Guadalajara y que estaban bajo su jurisdicción se les obligaba a cobrar al precio tasado ${ }^{46}$.

Durante los últimos años del siglo XVI una de las zonas más importantes por sus ventas al pósito de Guadalajara fue la Raya de Aragón y la comarca segoviana de Ayllón y que, al igual que las otras zonas de compra citadas, no siguieron la normativa establecida. En Ayllón, zona cabecera de la comarca y, por lo tanto, el lugar en el que se almacenaba el trigo comprado en ella, los portes entre diciembre de 1593 y mayo de 1594 fluctuaron entre los seis maravedíes transportados desde Santa María de Ayllón, y los diez desde Saldaña, a los doce desde Riaguas o los veinte que alcanzaron algunas partidas. En consecuencia a la ciudad de Guadalajara le salía cada una de estas fanegas entre veinticuatro y veintiséis reales, cuando el precio del trigo era de catorce reales la fanega.

$\mathrm{O}$, lo que es lo mismo, el precio por este concepto aumentó entre un 71,4 y un 85,7 por ciento sobre el precio inicial. Esta misma situación se repitió en 1599/1600, cuando los precios en Ayllón alcanzaron los doce y catorce maravedíes, que traducidos a dinero por cada fanega supuso, sólo en portes, un aumento añadido por cada una de ellas de 221 y 252 maravedíes, respectivamente ${ }^{47}$. Pero estas cantidades todavía subían un poco más a medida que los lugares de compra se encontraban más alejados de Ayllón, como el lugar de Calabazanos, situado a poco más de 100 kilómetros de este lugar, que sólo por los portes pagados por cada una de las fanegas compradas en él hasta el citado lugar de Ayllón se pagaron 215 maravedíes, que añadidos a los que había que pagar hasta llevarlos a Guadalajara elevó el precio final en más de un 100 por ciento.

En los primeros años del siglo XVII varió muy poco la situación, generalizándose el olvido de la tasa en los portes; por ejemplo, entre 1604 y 1605 éstos variaron entre los diez maravedíes del trigo comprado en Hita a los dieciséis que se llegaron a pagar en algunas zonas próximas a la Raya de Aragón, como en Yelo ${ }^{48}$. Estos mismos precios se volvieron a pagar en 1606 y 1607. Las razones para este importante aumento sobre el precio de la tasa, están muy relacionadas con las situaciones de precariedad en que se encontraba la ciudad, sin propios suficientes con los que hacer frente al pago de las importantes cantidades de trigo que se veía obligada a comprar y sometida a la propia exigencia de

\footnotetext{
46 En las cuentas tomadas a Luis de Lasarte queda claro cómo el trigo comprado en Cabanillas se pagó a precio de tasa: 14 rs el trigo y 10 los portes. AMGU. Leg. 1H42a-1.

47 Se compraron en Ayllón 1.818 fs por las que se pagaron a $14 \mathrm{mrs}$. de portes y 1.900 a 12 mrs por legua y fanega transportada. AMGU. Leg. 1h42b-3.

48 AMGU. Leg. $1 \mathrm{H} 43 \mathrm{a}-4$
} 
los arrieros locales quienes se sentían discriminados respecto a los forasteros, como en 1614, cuando la ciudad se vio obligada a pagarles por cada fanega transportada los dieciséis maravedíes en los que se había ajustado con los carreteros forasteros ${ }^{49}$.

\section{EVOLUCIÓN DEL PRECIO DEL TRIGO EN GUADALAJARA}

Dada la amplitud del período estudiado así como la diferencia de factores que influyeron en la evolución del precio del trigo, hemos procedido a dividirlo en varios subperíodos con el fin de ofrecer una mejor comprensión de todo el proceso, a la vez que nos ayude a analizar de una forma más pormenorizada la incidencia del pósito en el comportamiento general de estos precios en Guadalajara. Durante los cerca de cien años que comprende este estudio vamos a asistir a lo que Hamilton denominó como "Revolución de precios» fruto, entre otras causas, de la llegada masiva de metales preciosos de América y las numerosas guerras en las que estuvo inmersa Castilla en la segunda mitad del siglo

GRÁFICO III: ÍNDICES EFECTIVOS DEL PRECIO DEL TRIGO, 1546/1632 (MEDIA:1546-1632:100)

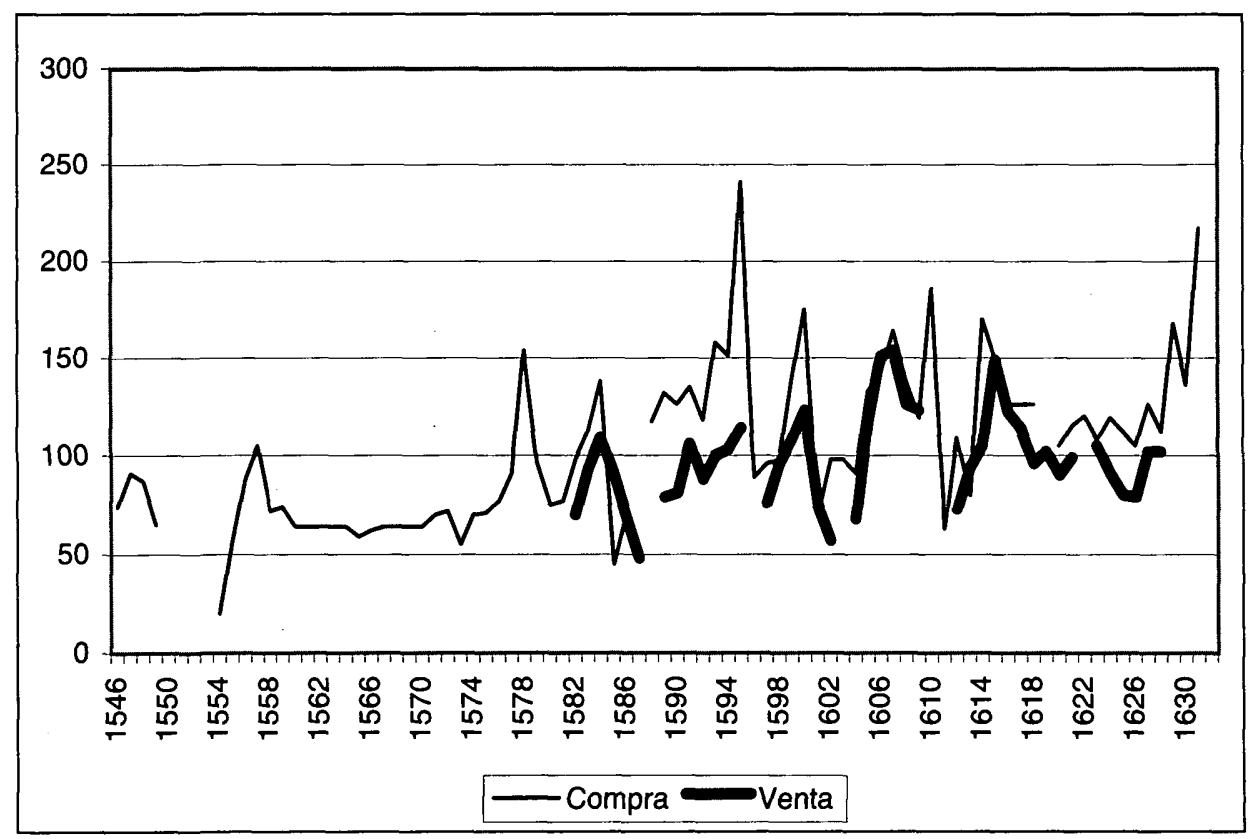

49 AMGU. Leg. 1H43a-4, 25 de julio de 1614. 
XVI. Su consecuencia más inmediata fueron las sucesivas bancarrotas padecidas por la Hacienda castellana durante el reinado de Felipe II y que, a nivel local, supuso un aumento considerable en el precio del trigo. Si nos atenemos a los índices efectivos obtenidos a partir de la media realizada sobre sus precios medios (1546-1632:100) se observa las fuertes oscilaciones que hubo a partir de los años ochenta del siglo XVI, alcanzando su punto máximo en 1595 con un índice de 241 por ciento, acompañado por precios que superaron el 170 por ciento como en 1600,1610 y 1614 , para terminar con una nueva cota máxima en 1632 , con un índice del 217 por ciento. Estos valores tan altos no son sino los indicadores propios de unos años en los que fue más patente la carestía, como la padecida en Guadalajara entre 1590 y 1595 , producto de las malas cosechas generalizadas en toda Castilla, y de la aportación que el pósito tuvo que hacer a la ciudad como adelanto de los 2500 ducados para el pago de los millones y que dejó sus arcas sin dinero para poder comprar trigo. La subida de los precios de 1600 tuvo su origen, a su vez, en las altas cantidades pagadas en los años anteriores y en la peste que asoló Castilla en 1599. El alza de1610 y 1614 tiene su origen en las malas cosechas y, sobre todo, en los embargos decretados por la Corte, más preocupada en abastecer Madrid que en procurar moderar los precios. Por último, la crisis de 1631/1632 no fue sino un resultado lógico de lo que venía ocurriendo en la ciudad en los años anteriores: mala administración del pósito y malas cosechas, que culminó con la desaparición de éste; momento que coincide con una abierta decadencia en la ciudad, no sólo económica en el más amplio sentido de la palabra, tras la marcha de los Mendoza, sino también poblacional, situación que se extenderá a lo largo de todo el siglo XVII ${ }^{50}$. Ahora bien, este perfil tan acusado que se aprecia en la gráfica de los índices efectivos no es tal si observamos las medias móviles, en este caso de cinco años, en los que se observan varias mesetas, en contraposición a la gráfica anterior, donde apenas si son perceptibles.

Los años ochenta del siglo XVI dejan de mostrar sus clásicos dientes de sierra para pasar a convertirse en una meseta de altura moderada, en comparación a la formada con los precios de los años sesenta y setenta de dicho siglo, donde se mantuvieron en unos índices medios en torno al 60 por ciento. Del mismo modo, las crisis de 1593/1594, de 1610 y de 1631 aparecen con unos perfiles más moderados en la gráfica de las medias móviles. Esta mejor predisposición de los precios en esos años se debe a la actuación del pósito, al ofrecer el trigo a los vecinos a un precio inferior al de compra. Así se observa que mientras la gráfica lineal sube de manera más pronunciada en los precios de compra, en cambio en los precios de venta presentan una línea más cercana a la horizontalidad, consecuencia de esta moderada subida en el precio.

so RUBIO FUENTES, Manuel: «Evolución demográfica de Guadalajara durante los siglos XVI y XVII», en Wad-Al-Hayara, $\mathrm{n}^{\circ}$ 25, Guadalajara, 1998. 
GRÁFICO IV: MEDIAS MÓVILES (5 AÑOS), 1546/1632.

(MEDIA: 1546-1632: 100)

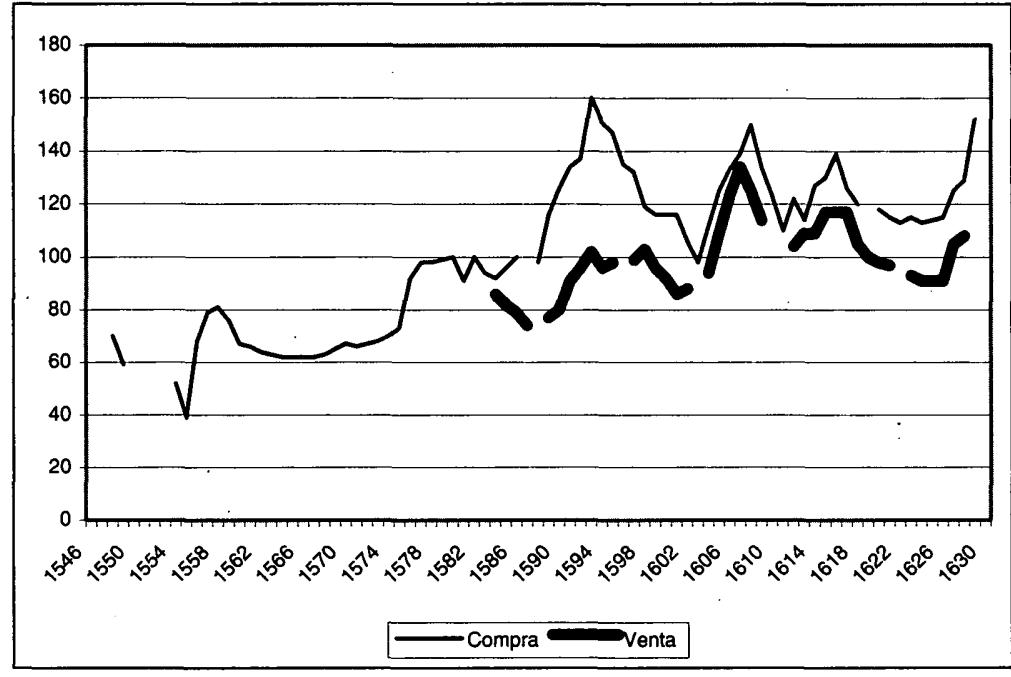

Teniendo en cuenta la duración de este período así como las diferentes circunstancias que durante estos años acontecieron sobre Guadalajara y su pósito lo hemos dividido en tres partes, con el fin de hacer más comprensible la evolución de los precios respecto al momento económico, para terminar con una apreciación global final. Cada una de ellas abarca períodos en torno a los treinta años. En primer lugar, hemos tenido en cuenta los primeros años de andadura del pósito, caracterizados por una tendencia moderadora en los precios, y que hemos situado entre 1546 y 1576 . En segundo lugar, el período comprendido entre 1576 y 1600, es quizá el más significativo de los tres, donde los precios experimentaron unas subidas más fuertes $\mathrm{y}$, sin duda, las de más repercusión en el devenir del pósito. Por último, el período comprendido entre 1601 y 1632, donde la conflictiva utilización que la ciudad venía haciendo del pósito dio como resultado su desaparición.

\subsection{6/1576: período de evolución moderada}

Los años comprendidos entre 1546 y 1576 presentan un primer momento en el que se dio una fuerte oscilación en el pecio del trigo, formando los característicos dientes de sierra; así vemos cómo entre 1556 y 1557 el aumento fue de un 42 por ciento sobre la media de los diez años precedentes. Los puntos que reflejan los máximos y los mínimos corresponden a los años de 1557 y 1553, respectivamente, con un máximo de 509 maravedíes y un mínimo de 
114, sobre los precios medios de la fanega de trigo. Esta diferencia coincidió con los primeros años de andadura del pósito, pero sin que éste tuviese todavía influencia alguna sobre ellos, siendo un mero reflejo de la situación observada en otras ciudades castellanas, como en Valladolid ${ }^{51}$. La causa de esta disparidad debemos achacarla a los métodos especulativos utilizados por los acaparadores y arrendadores ${ }^{52}$, ocupados en acumular el trigo durante los meses de la cosecha, que había sido buena ${ }^{53}$ en términos generales tanto en Guadalajara como en el resto de Castilla, para venderlo a mayor precio en los meses de abril, mayo y junio. Esta argumentación contrasta con la de Hamilton, quien considera que la causa de que los precios subieran en Castilla la Vieja en esos años fueron las malas cosechas de cereales ${ }^{54}$. En último término, el resultado más inmediato fue la imposición de una nueva tasa que entró en vigor el 20 de abril de 1558, que fijó la fanega de trigo en 310 maravedíes, es decir, elevó el precio máximo en más de un 80 por ciento sobre la tasa de 1539. Durante los años siguientes, los comprendidos entre 1560 y 1576 , los precios apenas si sufrieron variación, siendo su nota más característica la de su estabilidad, en torno a los 310 maravedíes de media, un precio muy moderado, en términos comparativos con el índice general realizado para todo el período. En esta moderación tuvo mucho que ver la actuación del pósito que ante la mala cosecha de trigo de 1570 y los problemas de abastecimiento que planteó a la ciudad, actuó de forma rápida y eficaz en 1571, repartiendo 90 fanegas diarias entre su población, impidiendo que los precios subieran más de lo establecido por la pragmática, al conseguir que el pan vendido en la plaza, cocido con el trigo del pósito, se vendiese a once maravedíes, frente a los diecisiete que valía el pan que entraba de fuera.

Los problemas de abastecimiento en el resto de Castilla, en especial durante 1568 , cuando Castilla la Vieja tuvo que importar trigo portugués ${ }^{55}$ trajeron como medida más inmediata la imposición de una nueva tasa, en 1571, que elevó el precio del trigo hasta los 374 maravedíes por fanega; siendo su primera consecuencia la subida del pan que alcanzó los doce maravedíes de media, para bajar de nuevo en los años siguientes hasta los nueve y diez maravedíes, precios relativamente bajos si tenemos en cuenta la fuerte subida que experimentó en los años siguientes.

51 BenNassar, Bartolomé: Valladolid en el Siglo de Oro. Una ciudad de Castilla y su entorno agrario del siglo XVI, Valladolid, 1989, p. 263.

52 Las primeras noticias sobre esta culpabilidad las vio el Concejo en su reunión del 15 de diciembre, en la que se recoge una Provisión Real acusándoles de esta subida de precios. AMGU. L.A., y pocos días más tarde, de nuevo a través de otra Real Provisión, Valladolid, 6 de febrero de 1557. AMGU. Leg. 1H4.001, vuelven a incidir en lo mismo.

53 Real Provisión, Valladolid, 20 de noviembre de 1557. AMGU. Leg. 1H4.001.

54 HAMILTON, Earl J: El tesoro americano y la revolución de los precios en España, 1501-1650, Barcelona, 1983, p. 214.

5s BRUMONT, Francis: Campo y campesinos de Castilla la Vieja en tiempos de Felipe II, Madrid, 1984 , p. 37.

Hispania, LXIII/3, núm. 215 (2003) 863-906 
PRECIO COMPRA DE TRIGO EN MARAVEDÍES POR FANEGA, 1546/1576.

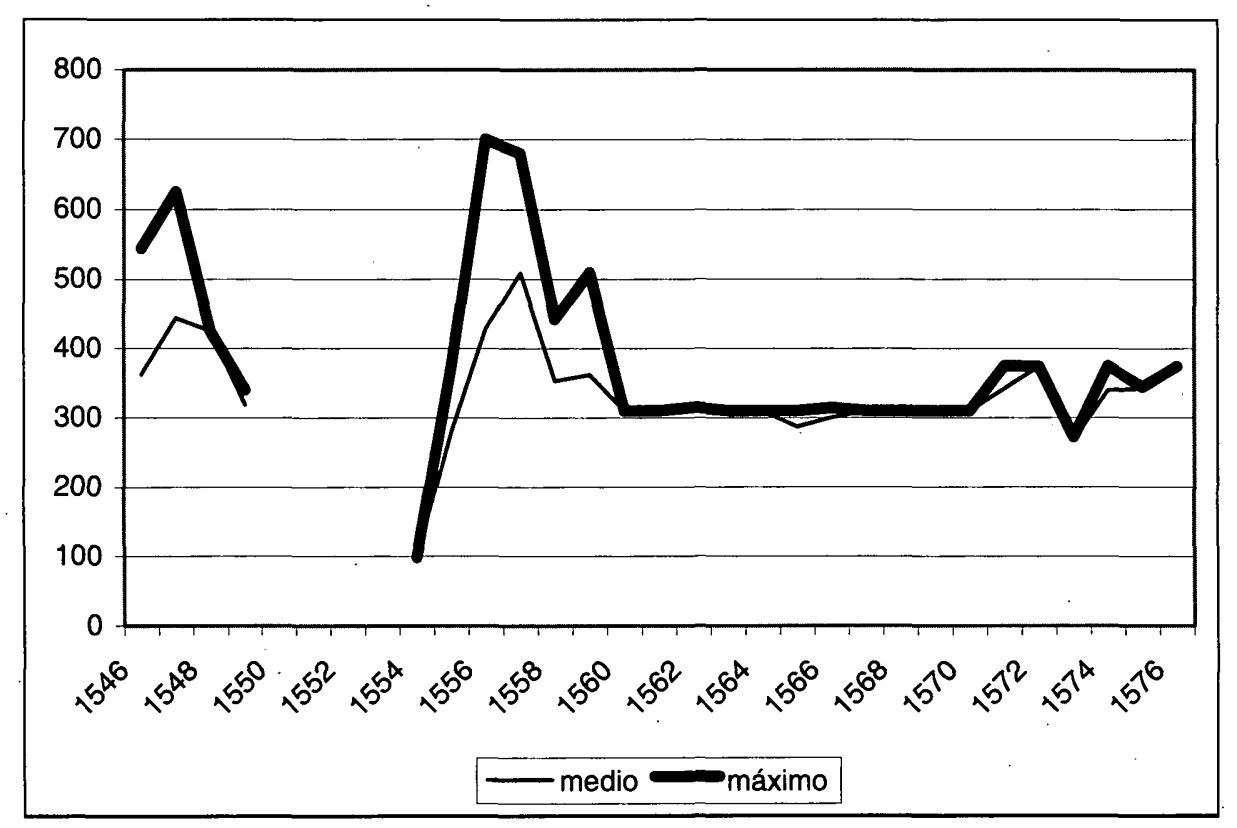

\subsection{7/1600: período de rápido crecimiento de los precios}

Tras la relativa estabilidad del período anterior, los años de 1577,1578 y 1579 supusieron una fuerte sacudida en los precios a consecuencia de las malas cosechas de los dos años precedentes y de la bancarrota de la hacienda castellana de 1575; los precios del trigo llegaron a subir, durante los dos primeros años, en torno al 40 por ciento sobre la media del período, alcanzando un precio máximo de 680 maravedíes por fanega en 1577, y de 748 en 1579, un 90 por ciento más de la media, lo que obligó a la ciudad a destinar a la compra de trigo los 30000 ducados tomados a censo ante el cariz que estaba tomando la falta de trigo. A partir de esta fecha los precios sufrieron una fuerte convulsión que se extendió hasta finales de siglo; esta misma tendencia alcista se observa en Inglaterra donde, según Wrigley, en 1596 tuvo lugar la peor cosecha de la Edad Moderna ${ }^{56}$. Tras esta primera crisis se sucedieron años de relativa estabilidad hasta 1582 , donde la tendencia cambió de forma radical, sólo rota de manera puntual los años 1585 y 1586 , cuando éstos cayeron hasta en un 66

56 WRIGLEY, E.A:. Gentes, ciudades y riqueza. La transformación de la sociedad tradicional, Barcelona, 1992, p. 155 .

Hispania, LXIII/3, núm. 215 (2003) 863-906 
por ciento respecto a 1584 , año éste de especial incidencia de la crisis, siendo preciso salir en busca del trigo hasta Tierra de Campos, así como a proceder a un registro generalizado en toda la Tierra de Guadalajara. La crisis de esos años provocó la descapitalización del pósito que se vio agravada por la oposición de algunos vecinos a registrar su trigo, siendo necesario pedir varios censos con los que afrontar esta compra.
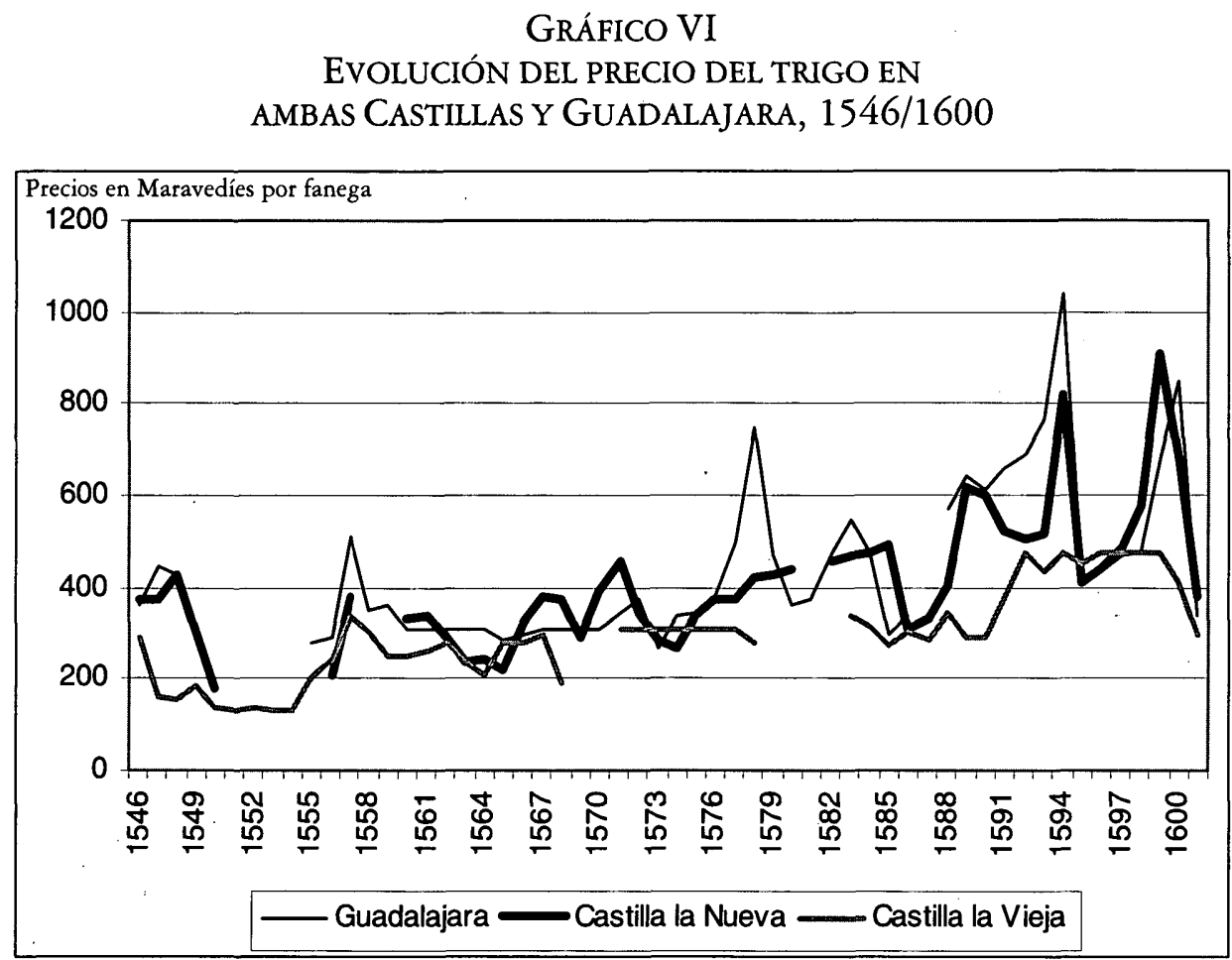

Esta crítica situación sólo fue un aperitivo de lo que se avecinaba, ya que desde 1588 hasta 1595 asistimos a un período alcista sin precedentes; los precios subieron de forma rápida hasta alcanzar su punto culminante en 1595 , en donde el trigo alcanzó un valor máximo de 1167 maravedíes, o lo que es lo mismo, un 200 por ciento más sobre el precio de 1586 y de un 100 por ciento sobre el precio de 1588. Esta tendencia alcista coincide con otros lugares, como en Castilla la Vieja donde se tuvo que comprar, trigo portugués en $1594^{57}$, al igual que ocu-

57 BRUmont, Francis: Campo y campesinos de Castilla la Vieja en tiempos de Felipe II, Madrid, 1984 , p. 37. 
rriera en 1568 , en especial en algunas ciudades como Valladolid, aunque en ella esta tendencia continuó hasta finales de siglos8; en Barcelona, donde el período de mayor alza relativa tuvo lugar entre 1599 y $1600^{59}$; o en Navarra ${ }^{60}$.

Si nos atenemos a las subidas que experimentó el trigo en cada uno de los años que duró esta crisis y su evolución por trimestres, se comprueba que no hay ningún trimestre del año en el que se produzcan unas subidas más espectaculares respecto al resto; así mientras que en unas ocasiones estas subidas son mayores en los meses del invierno, como en 1592 y 1594 , en otras los precios más altos se dieron en pleno verano, como en 1591, o en el otoño, como ocurrió en 1593. En todos los casos las alzas se produjeron por la compra de trigo en lugares situados fuera de la jurisdicción de Guadalajara, por lo que a los precios de compra hubo que añadir los portes y demás gastos. En cambio los precios más bajos corresponden al trigo comprado en la jurisdicción, casi siempre al precio de tasa.

\section{GRÁFICO VII \\ EVOLUCIÓN DEL PRECIO DE COMPRA ENTRE 1591/1594}

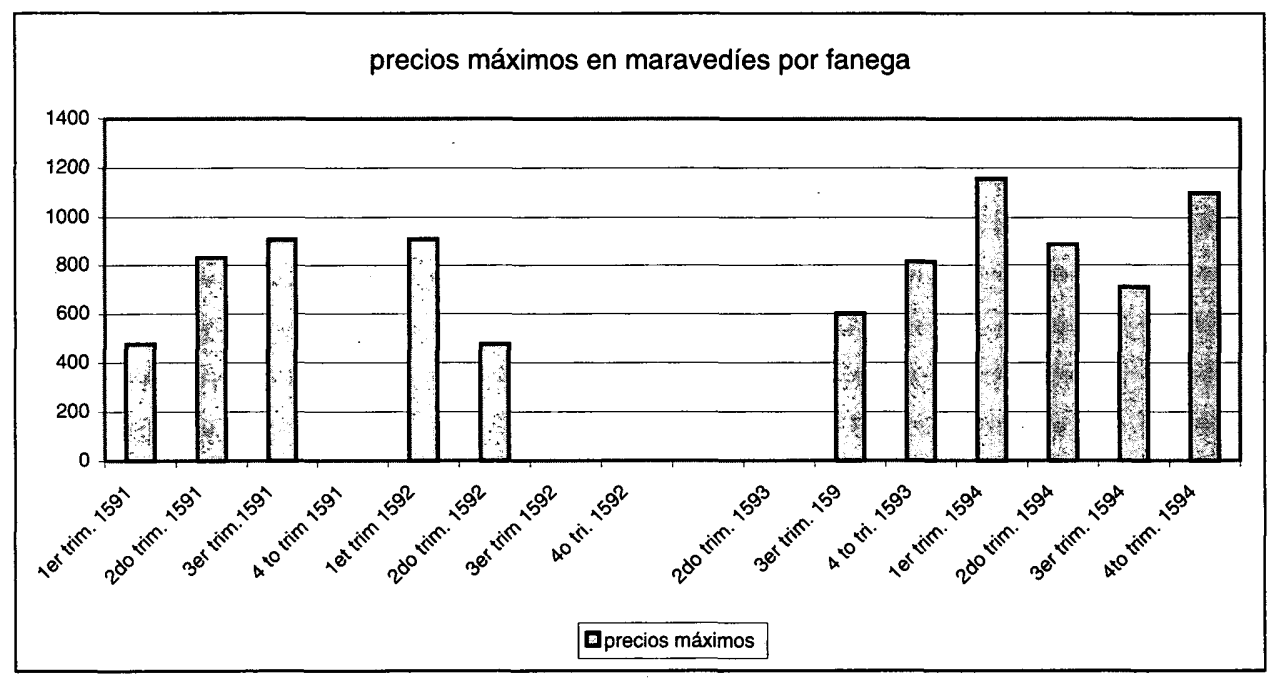

58 BenNASSAR, Bartolomé. Bartolomé: Valladolid en el Siglo de Oro. Una ciudad de Castilla y su entorno agrario del siglo XVI, Valladolid, 1989, p. 263.

59 FeliU, Gaspar: «Precios y salarios en la Cataluña Moderna», en Estudios de Historia Económica (Madrid) 21 (1991), p. 26.

60 ARIZCUN CELA, Alejandro: «Series navarras de precios de cereales, 1589-1841», en Estudios de Historia Económica, (Madrid) 18( 1989) , p. 96.

Hispania, LXIII/3, núm. 215 (2003) 863-906 
Tomando las series de precios de Hamilton sobre los valores alcanzados por el trigo y referidas a las dos "Castillas», comprobamos que en Castilla la Nueva los precios sufrieron un alza generalizada durante los últimos años del siglo XVI, siendo el año 1599 cuando los precios alcanzaron su valor máximo. En cambio, si nos referimos a Valladolid, por ejemplo, los puntos de encuentro son muchos más que con el sur castellano, debido a que esta zona era por entonces la principal zona abastecedora de trigo de Guadalajara en momentos de crisis. Según Bennassar, los precios en Valladolid subieron de forma espectacular desde 1591, cuyos índices a partir de este año superan ampliamente el 200 por ciento, para llegar a 1594, como punto más alto de la gráfica, en el que los

\section{GRÁFICO VIII}

EVOLUCIÓN DEL PRECIO DE COMPRA DEL TRIGO, 1577/1600

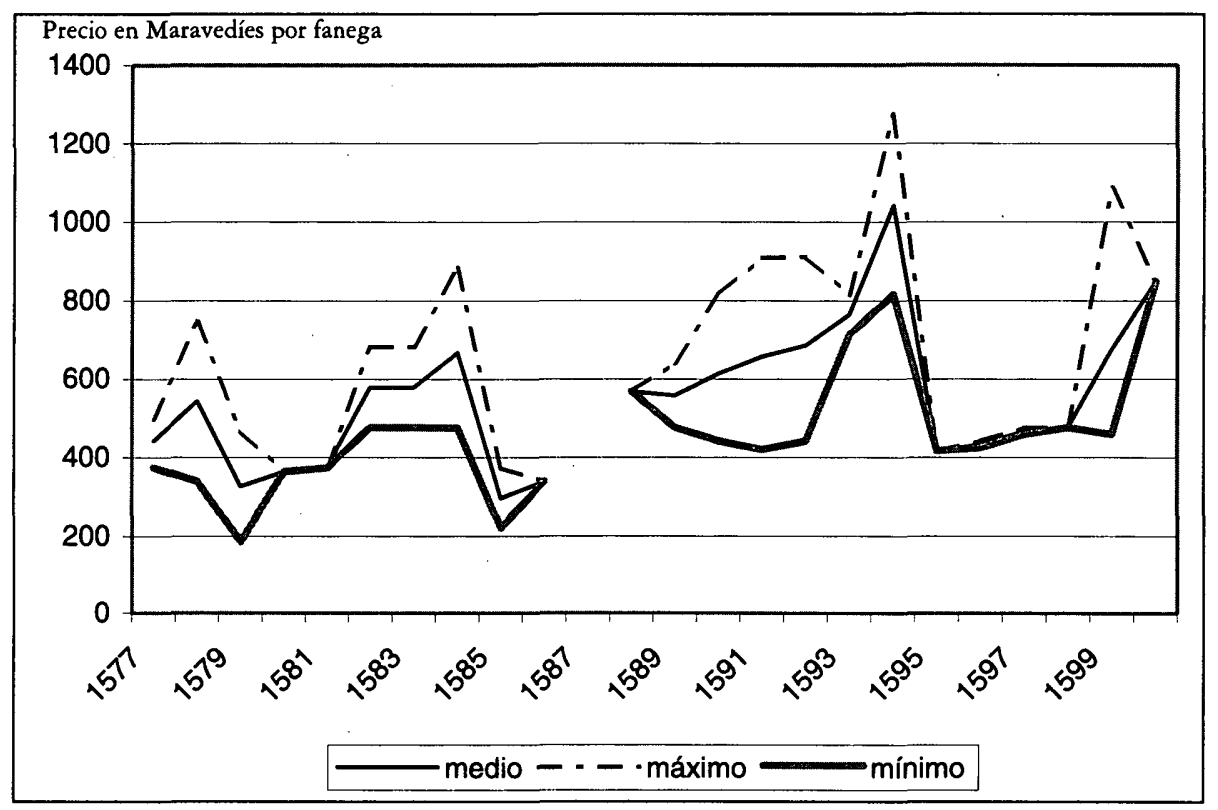

precios alcanzaron un índice de más del 300 por ciento ${ }^{61}$. Estos precios tan elevados en un lugar considerado tradicionalmente como cerealista nos permite comprender en mejor medida la subida de precios experimentada en Guadalajara durante estos años. Si lo comparamos con el resto de Castilla la Nueva, el

61 BeNNASSAR, Bartolomé: Valladolid en el Siglo de Oro. Una ciudad de Castilla y su entorno agrario en el siglo XVI, Valladolid, 1989, p. 262. 
alza es más espectacular en Guadalajara durante los años comprendidos entre 1588 a 1595 que en el resto de la región. Así, por ejemplo, si partimos de los precios pagados en el primer trimestre de 1591, año inmerso en plena crisis, con los pagados en ese mismo período en 1592 se aprecia una subida del 91,5 por ciento y del 142,8 por ciento si lo comparamos con el primer trimestre de 1594. Estas subidas, que a simple vista no parecen muy exageradas, supusieron unas cotas de casi 1200 maravedíes por fanega de trigo comprada en esta última fecha, fiel reflejo de los altos precios pagados en todo ese quinquenio. A esta subida le sucedieron tres años los de 1596, 1597 y $1598^{62}$, de relativa bonanza, en los que los precios permanecieron en torno al índice 100, tomando como medida todo el período, para de nuevo volver a subir durante los dos últimos años del siglo, hasta un 50 por ciento sobre la media, aunque sin llegar a las cotas alcanzadas en 1595 .

\section{GRÁFICO IX}

TENDENCIAS DE LA MEDIA MÓVIL DEL PRECIO DEL TRIGO, 1577/1600

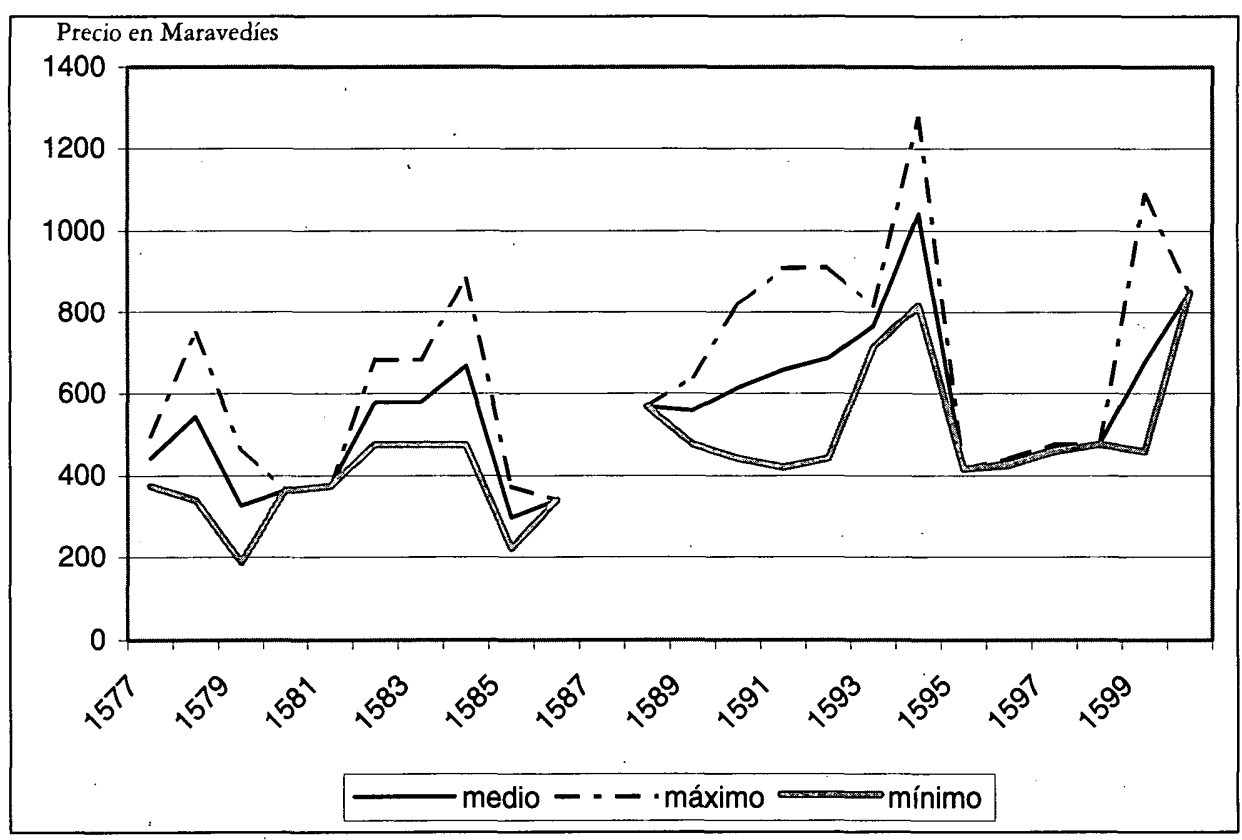

62 En cambio en Madrid los precios máximos se dieron entre 1595 y 1600 . RINGROSE, David R.: Madrid y la economía española 1560-1850. Ciudad, Corte y País en el Antiguo Régimen, Madrid, 1985, p. 139.

Hispania, LXIII/3, núm. 215 (2003) 863-906 
¿A qué se debe esta diferencia de precio en un año tan significativo dentro de las crisis tradicionales de subsistencias? ¿Acaso no hubo problemas de abastecimiento en Guadalajara? En primer lugar, debemos apuntar que si en Guadalajara se notó en menor medida esta crisis en 1599 se debió a la labor del pósito, ya que si bien durante 1599 se vio obligado a comprar trigo fuera de sus comarcas naturales, llegando hasta Sisamón y Cetina, pertenecientes a la Raya de Aragón, donde se pagaron precios de hasta un máximo de 816 maravedíes por fanega de trigo (incluidos todos los conceptos), el hecho de que también se comprase en los lugares de la Tierra, a través de las requisas llevadas a efecto por el método del conocido "pan de registro", pagándolo al precio de la tasa, hizo que el precio final de venta del trigo a la población fuese menor; en comparación con otros lugares. Aunque, sin duda, lo que más influyó fue la actuación del pósito, que durante el año de mayor incidencia de la crisis, 1598/1599, repartió casi el 100 por ciento de las 16907 fanegas almacenadas, permitiendo que su población no quedara desabastecida, a la vez que sirvió para rebajar el precio final del trigo.

CUADRO X

EVOLUCIÓN DEL TRIGO Y DINERO DEL PÓSITO ENTRE 1584 Y 1600

\begin{tabular}{|l|c|c|c|r|r|r|}
\hline AÑOS & $\begin{array}{c}\text { CARGO } \\
\text { TRIGO }\end{array}$ & $\begin{array}{c}\text { DESCARGO } \\
\text { TRIGO }\end{array}$ & $\begin{array}{c}\text { TANTO POR } \\
\text { CIENTO }\end{array}$ & $\begin{array}{c}\text { CARGO } \\
\text { DINERO }\end{array}$ & $\begin{array}{c}\text { DESCARGO } \\
\text { DINERO }\end{array}$ & $\begin{array}{r}\text { TANTO } \\
\text { POR } \%\end{array}$ \\
$1584 / 87$ & 25.161 & 24.765 & $98,42 \%$ & 29.703 .544 & 28.364 .416 & 95,43 \\
$1587 / 88$ & 12.258 & 8.673 & $70,75 \%$ & 2.036 .516 & 2.049 .179 & 100,63 \\
$1588 / 89$ & 12.258 & 6.014 & $49,06 \%$ & & & \\
$1589 / 90$ & 12.445 & 12.328 & $99,05 \%$ & 5.186 .502 & 1.779 .904 & 34,30 \\
$1590 / 91$ & 16.444 & 16.421 & $99,86 \%$ & 18.096 .192 & 17.935 .307 & 99,11 \\
$1591 / 92$ & 11.810 & 11.412 & $96,62 \%$ & 8.991 .870 & 8.638 .952 & 96,07 \\
$1592 / 93$ & 14.522 & 9.700 & $66,79 \%$ & 11.589 .816 & 15.678 .573 & 135,28 \\
$1593 / 94$ & 14.784 & 14.024 & $94,85 \%$ & 13.315 .607 & 11.612 .900 & 87,20 \\
$1594 / 95$ & 11.737 & 4.234 & $36,07 \%$ & 7.264 .400 & 5.944 .183 & 81,82 \\
$1595 / 96$ & 11.687 & 4.346 & $37,18 \%$ & 7.846 .848 & 6.221 .873 & 79,28 \\
$1596 / 97$ & 11.810 & 11.412 & $96,62 \%$ & 8.991 .185 & 8.638 .952 & 96,07 \\
$1597 / 98$ & 10.720 & 8.206 & $76,54 \%$ & 6.820 .621 & 6.510 .137 & 95,45 \\
$1598 / 99$ & 16.907 & $165: 29$ & $97,76 \%$ & 14.720 .853 & 13.643 .745 & 92,68 \\
$1599 / 00$ & 16.165 & 7.326 & $45,32 \%$ & 8.138 .557 & 8.872 .456 & 109,01 \\
\hline
\end{tabular}

Esta política de repartimiento lo utilizó la ciudad cada vez que fue necesario. En general el trigo entregado a los vecinos sirvió, a partir de 1584, no sólo para que éstos tuviesen pan cocido sino también para que pudiesen sembrar sus barbechos, ya que ellos habían gastado el trigo que almacenaban en espera de 
la siembra. Si observamos el cuadro del trigo entregado entre 1584 y 1600 se comprenderá mejor la labor desarrollada por el pósito durante los últimos años del siglo XVI. En los repartimientos realizados vemos que los años 1584/1587, 1589/1592, 1593/1594, 1596/1597, 1598/1599 marcaron los puntos cenitales de éstos, en los que la actuación del pósito al entregar casi el 100 por ciento de sus existencias permitió que la ciudad no sintiera las crisis de subsistencias que azotaban Castilla con tanta intensidad.

En cuanto al precio del pan siguió el mismo proceso alcista que el trigo, sólo moderado por la actuación del pósito que entregaba a los panaderos un número determinado de fanegas para su cocción y posterior reparto por parroquias. El precio del pan que podemos considerar como normal para todo el período fue el de 14 maravedíes, sin embargo pocas fueron las ocasiones en las que se pudo vender a este precio, ni siquiera la actuación del pósito pudo evitar las sucesivas subidas, aunque sí las moderó. Desde 1578 a 1600 se alcanzaron precios máximos nunca vistos hasta entonces, que tuvieron su punto culminante en 1600 cuando se llegaron a pagar hasta 24 maravedíes por pan, cuando el precio mínimo era de 22 , precios prohibitivos para la población, que no podía pagar máxime en unos momentos en los que se hallaba enfrentada a otro grave problema como era la peste.

GRÁFICO XI

EVOLUCIÓN DEL PRECIO MEDIO DEL PAN DE DOS LIBRAS, 1578/1600

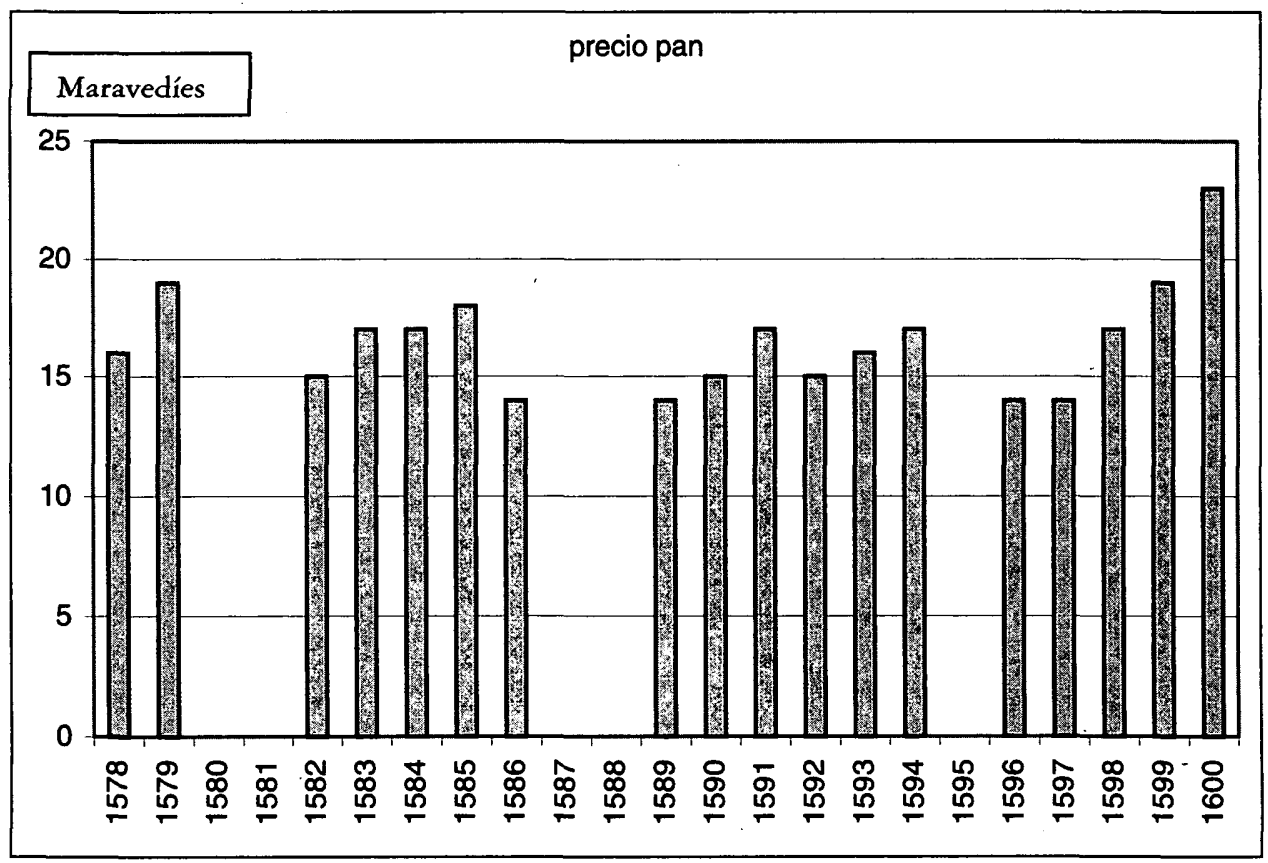

Hispania, LXIII/3, núm. 215 (2003) 863-906 


\subsection{De la lenta agonía del pósito hasta su desaparición, 1600/1632}

El comienzo del nuevo siglo trajo consigo una inversión en la tendencia; hubo una buena cosecha, cifrada en un 56 por ciento superior a la del año anterior $^{63}$, lo que unido a las buenas noticias sobre el fin de la peste, sirvió para aliviar los problemas de abastecimiento de los últimos años. Sin embargo, en lo que se refiere a los precios éstos no sólo no bajaron sino que subieron, alcanzando un índice del 175 por ciento. La causa hay que buscarla en la actuación del propio pósito cuyos efectos en relación con el consumidor fueron los contrarios al período anteriormente estudiado; los altos precios pagados por el trigo comprado en los años de carestía y los que tuvieron que pagar todavía a principios de año, 850 maravedíes $^{64}$, se convirtieron en el principal obstáculo para que éstos bajasen en Guadalajara a pesar de la buena cosecha de 1600. El Concejo temiendo una gran pérdida para el pósito, donde tenía almacenadas importantes cantidades de trigo y ante la poca demanda que los vecinos hacían de él, ya que el que se vendía en la plaza costaba a menos precio, obligó a los panaderos y labradores a llevarse el trigo almacenado en el pósito a los precios pagados por éste ${ }^{65} \mathrm{o}$, como mal menor, a un precio sensiblemente rebajado, con la finalidad de que la pérdida no fuera muy elevada ${ }^{66}$.

Esta medida aparte de elevar el precio del trigo sobre el establecido en la plaza provocó la escasez de pan durante el mes de julio, al negarse los vecinos a comprarlo, a pesar de que para entonces este precio había bajado considerablemente, desde los 850 maravedíes por fanega, precio alcanzado en el mes de marzo a los 578 en el mes de julio. Este último precio lo había fijado el Concejo teniendo en cuenta que con las compras realizadas por el pósito tras la nueva cosecha, éste había bajado sensiblemente el valor medio del trigo almacena$\mathrm{do}^{67}$, aunque todavía seguía siendo muy alto para los más pobres en comparación al precio de mercado. Finalmente, la ciudad optó por recurrir a una medida ya vieja: vender a los más pudientes de la ciudad 1500 fanegas al precio establecido y permitir la entrada de trigo forastero en la ciudad, aunque de forma efímera pues de nuevo en marzo de 1601 se volvió a la antigua prohibición en tanto no se vendiese el trigo del pósito. Los precios en los años siguien-

63 En 1599 se recogieron 3581 fs frente a las 5609 del año 1600. En López SaLAZAR, Jerónimo y MARTín GALÁN, Manuel: "La producción cerealistica en el arzobispado de Toledo, 1463-1699», en Cuadernos de Historia Moderna y Contemporánea, (Madrid) Vol. II (1981), p. 78.

64 Se habían comprado 10000 fs en Tierra de Campos a un precio medio (con salarios, costas, portes, ...) de 25 rs la fa. AMGU. L.A., sesión del 4 de marzo de 1600.

65 AMgU. L.A.: sesión del 17 de abril de 1600.

66 Baltasar de Villafaña, mayordomo del pósito, pidió al Concejo que ante la buena cosecha que se avecinaba se vendiese el trigo del pósito a un menor precio del pagado, para evitar daños mayores, ya que el tiempo estaba muy húmedo y se podía agorgojar el trigo. AMGU. L.A., 28 de mayo de 1600 .

67 AMgu. L.A., 17 de julio de 1600.

Hispania, LXIII/3, núm. 215 (2003) 863-906 
tes, hasta 1604 inclusive, mantuvieron el índice 100, al igual que en el resto de Castilla o en Navarra, por ejemplo, a pesar de que las cosechas fueron normales, excepto en 1602 donde el índice subió claramente del $100^{68}$. A partir de 1605 esta tendencia se rompió, comenzando un largo período que se extendió hasta 1610 , en el que los precios se dispararon de nuevo, al igual que en otros lugares de Castilla la Nueva ${ }^{69}$, Navarra ${ }^{70}$ o Sevilla ${ }^{71}$.

El precio máximo se alcanzó en 1607, fecha en que se pagaron algunas partidas a 1020 maravedíes, aunque la media más alta para todo el año correspondió a 1610, que se alcanzaron los 910 maravedíes. Las causas de este considerable aumento, que hizo que se alcanzase un 186 por ciento de índice, hay que buscarlo no sólo en las malas cosechas de los años que van de 1605 a 1608, en especial en 1606, cuyo índice quedó situado en el 56 por ciento, sino también en el poco estímulo que tenían los labradores para sembrar. Así al menos lo hicieron saber los regidores alcarreños Pedro de Alarcón y Luis de Guzmán a Felipe II en 1607 con motivo de la promulgación de la pragmática sobre los oficios perpetuos de los lugares y villas eximidas y sobre la conveniencia de que bajase el precio del pan ${ }^{72}$. Éstos opinaban que la causa de que la mitad de la tierra estuviese en barbecho se debía a la tasa sobre el trigo, ya que los labradores en los años de malas cosechas, como en los años anteriores, le salía la fanega de trigo, una vez pagados los jornales, a 1125 y 1500 maravedíes la fanega, que al tener que vender de forma obligatoria al precio de la tasa sólo conseguía recuperar 612 maravedíes, siendo la pérdida considerable.

La actuación del pósito en este sentido, entregando más del 90 por ciento del trigo almacenado entre los vecinos, si exceptuamos el año 1608/1609, que se quedó en el 80 por ciento, no deja lugar a dudas de que la crisis fue muy importante, lo suficiente como para determinar que este período marcó el punto de inflexión a la baja del pósito, que al igual que ocurriera con la aplicación de la tasa, fue criticado duramente por los regidores mencionados, al considerar que los pósitos eran los causantes, por su mala administración, de que los pueblos estuvieran tan exhaustos. Esta apreciación choca frontalmente con la propia actuación de los concejos ya que ellos eran los que en último término permitían

68 LóPEZ-SALAZAR, Jerónimo y MARTín GaLÁN, Manuel: «La producción cerealística en el arzobispado de Toledo, 1463-1699", en Cuadernos de Historia Moderna y Contemporánea, (Madrid) Vol. II (1981), p. 78.

69 Entre 1600 y 1620 los precios del trigo crecieron más en Castilla la Nueva que en Castilla la Vieja por la presión que ejerció Madrid sobre el mercado. PÉrEZ, Ural A.: «El precio de los granos en la Península Ibérica: 1585-1650», en Anuario del Instituto de Investigaciones Históricas, (Rosario) vol. 8, (1965), pp. 128-134.

70 AruzCum Cela, Alejandro: «Series navarras de precios de cereales, 1589-1841»; en Estudios de Historia Económica, (Madrid) 18( 1989) + 110 págs.

71 PONSOT, P.: Atlas de Historia Económica de la Baja Andalucía (siglos XVI al XIX), Sevilla, 1986, Óp. cit., pp. 520-522.

72 AMGU. L.A., 18 de julio de 1607. 
que éstos estuviesen mal administrados, desde el momento mismo de que elegían como mayordomos a personas que nada conocían de estos menesteres ${ }^{73}$.

\section{GRÁFICO XII}

PRECIO DE COMPRA DE TRIGO, 1601/1632

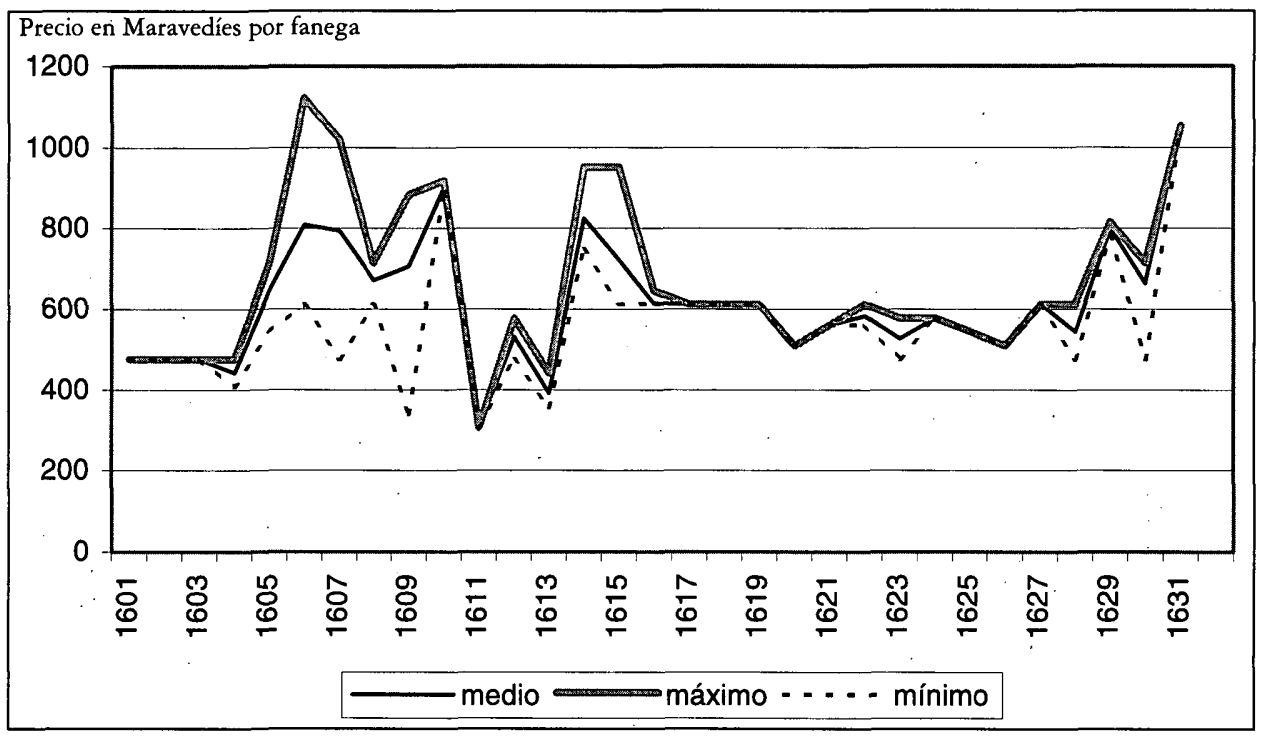

A partir de entonces la capacidad de almacenaje del pósito fue disminuyendo de forma progresiva hasta su desaparición en 1632 fruto, entre otros, de la mala administración de dos de sus mayordomos Juan del Pozo (1606-1611) y Sebastián Suárez (1611-1617); del abuso de la ciudad respecto al dinero del pósito; y, en definitiva, por la grave crisis económica y de población en que estuvo inmersa Guadalajara a partir de estos años. Podemos establecer un período de decadencia mitigada hasta 1617 , para a partir de ese momento hablar de una caída en picado.

La tendencia en el precio del pan durante los primeros años del siglo XVII siguió la misma tónica alcista que el trigo. Tras los tres/cuatro años iniciales en los que éstos se mantuvieron en torno a los 14 maravedíes la evolución en el precio del trigo a partir de 1605 provocó una subida en el pan de un 42 por ciento, respecto a 1604 , y de un 85 por ciento en 1606 , donde se alcanzó un precio medio de 26 maravedíes. Esta tendencia alcista se mantuvo sin solución de continuidad a lo largo de los años siguientes con la excepción hecha de 1612 en el que

73 Por ejemplo, Sebastián Suárez era boticario y Alonso Ruiz, ministril( músico). 


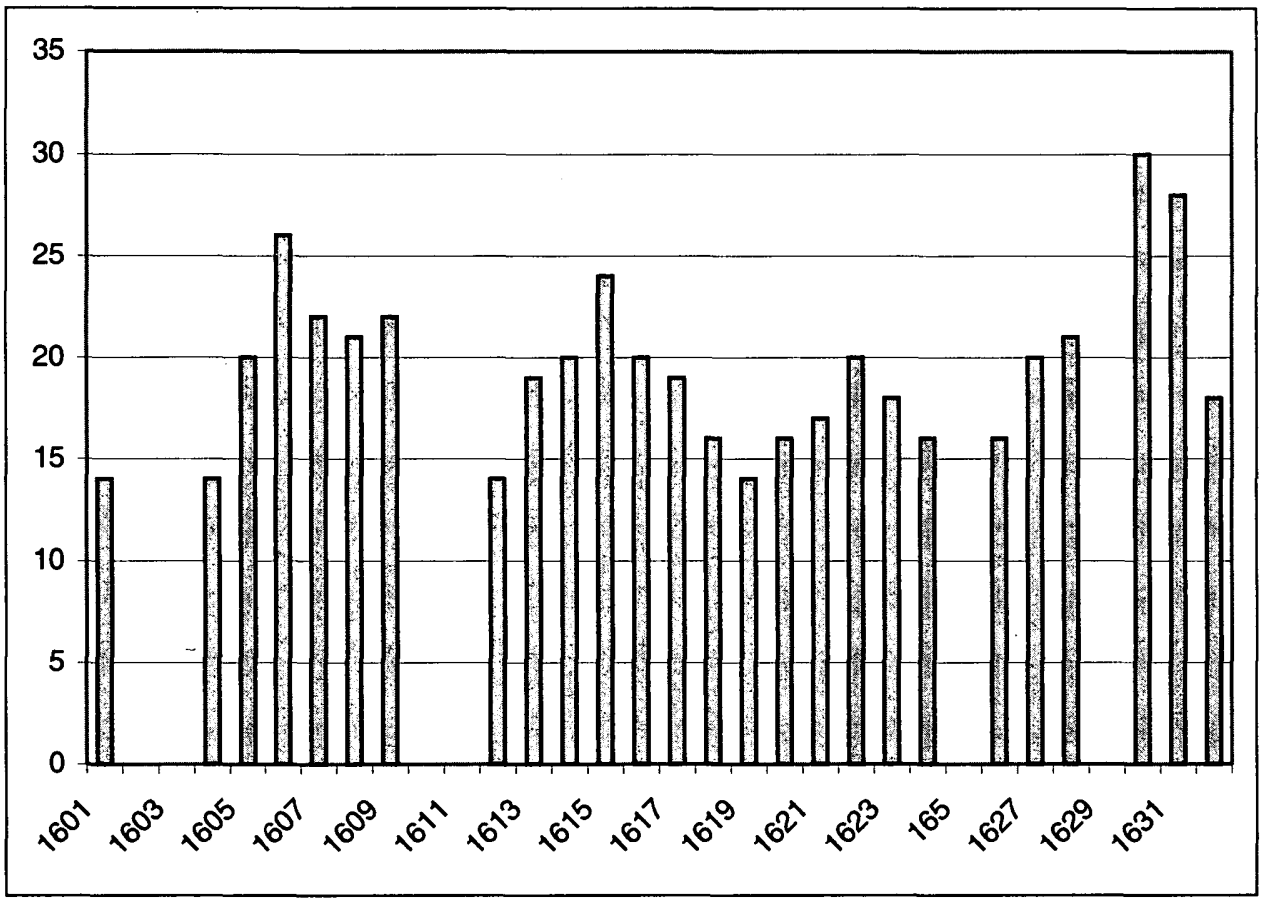

de forma pasajera se redujo a 14 maravedíes. El período entre 1614 y 1622 se caracteriza por unos precios claramente superiores al índice 100, en los que sobresale el primer año, 1614, que alcanza el 170 por ciento, y que se corresponde con un año de malas cosechas, frente al año 1619 , del que a pesar de que no disponemos de precios sabemos, por los Libros de Acuerdos examinados, que hubo una gran cosecha en 1618, expresada en una menor petición de trigo por parte de los labradores. La acción del pósito en estos años la podemos considerar como de puro trámite, inmerso ya en una profunda crisis, endeudado y sin apenas actividad compradora y menos aún vendedora, debido a que el trigo almacenado estaba en malas condiciones, a causa de los excesivos años de almacenaje.

Las compras realizadas en 1614 en La Mancha, a los Fúcares, de 6000 fanegas del trigo que tenían en Villanueva de los Infantes, en los Campos de Montiel $^{74}$; las 2000 fanegas compradas en Zamora ${ }^{75}$, así como el hecho de que el ma-

74 AMGU. L.A., 25 de julio de 1614.

75 AMGU. Leg. 1H43b-6.

Hispania, LXIII/3, núm. 215 (2003) 863-906 
GRÁFICO XIV

VALORES COMPARATIVOS DE LA COMPRA-VENTA DE TRIGO. 1546/1632

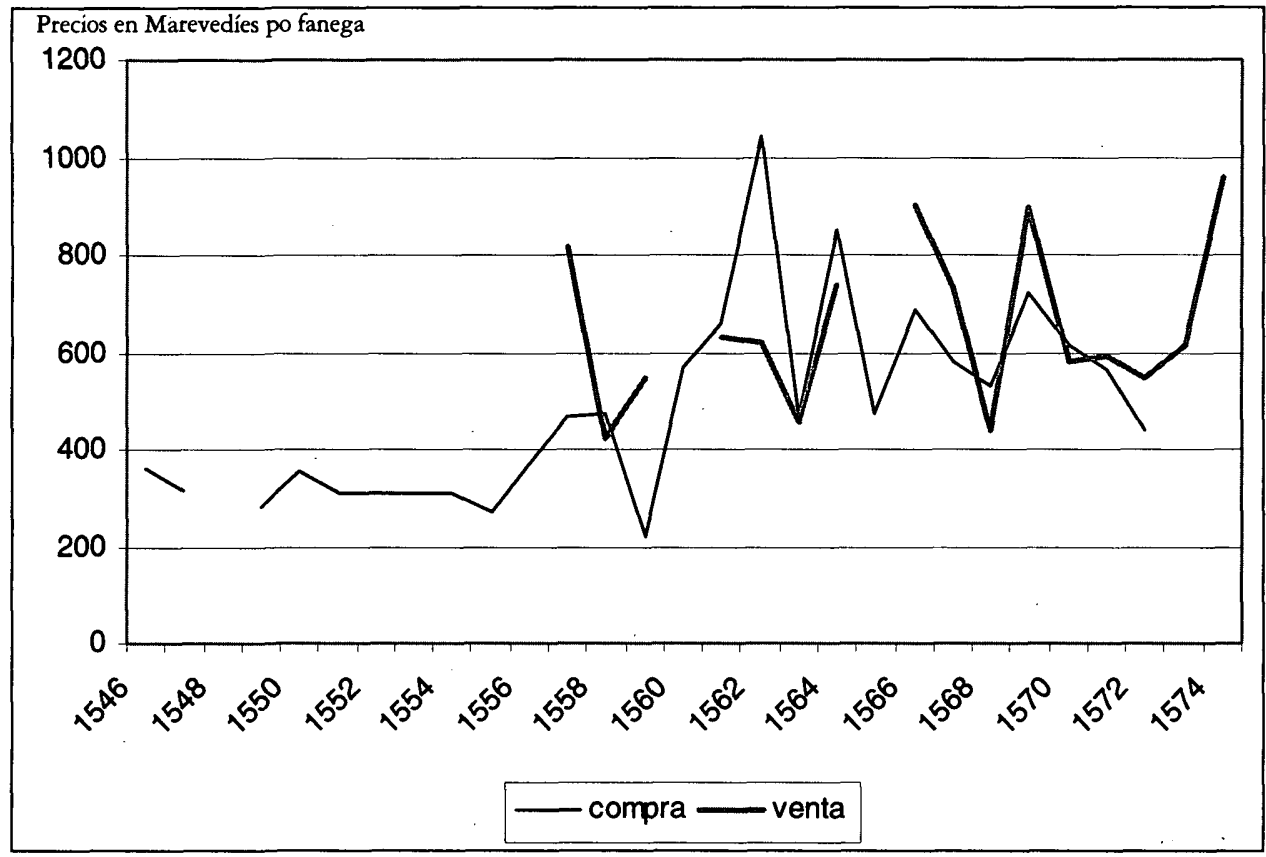

yordomo del obispo de Ávila se ofreciese a vender a la ciudad 6000 fanegas en Arévalo, marcaron las últimas actuaciones compradoras a gran escala del pósito fuera de los lugares de la jurisdicción de Guadalajara, debido a la poca capacidad económica que le quedó una vez comprobadas las deudas contraídas con él por la ciudad y sus vecinos ${ }^{76}$. Esta misma tendencia la volvemos a observar en los precios del pan que se situaron en una media entre los 18 y los 20 maravedíes, con pequeñas excepciones, como la de 1619 , único año donde el precio se mantuvo en los 14 maravedíes, consecuencia de la buena cosecha del año anterior.

Los últimos coletazos del pósito poco tuvieron que ver ya con los precios que se dieron entre 1629 y 1631 . En estos tres años los precios alcanzaron unos valores muy altos, siendo 1631 , con un índice de 217 por ciento, el año en que más subieron, sin duda por la pobre cosecha recogida durante 1630 , con un índice del 65 por ciento ${ }^{77}$. Esta tendencia alcista se repitió de nuevo en el resto

76 En 1614 se deben al pósito un total de 2.461 fs entre los bienes comunes, varios particulares y los monasterios. AMGU. L.A., 21 de octubre de 1614.

77 LÓPEZ SALAZAR, Jerónimo y MARTíN GALÁN, Manuel: «La producción cerealística en el arzobispado de Toledo, 1463-1699", en Cuadernos de Historia Moderna y Contemporánea, (Madrid) Vol. II (1981), p.60. 


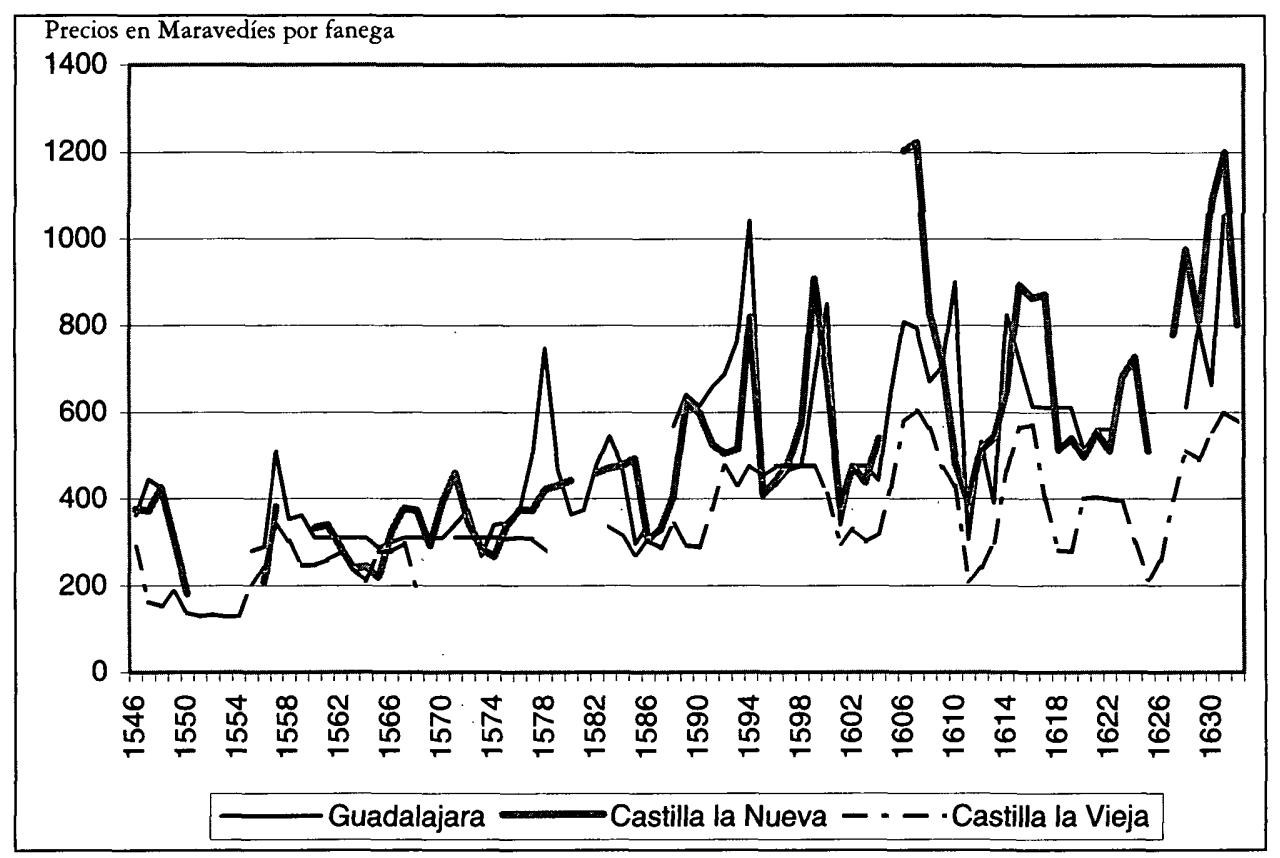

de Castilla, si nos atenemos a los precios estudiados por Hamilton, y en otras regiones españolas como en Navarra, por ejemplo. En cuanto a los precios del pan se alcanzaron los más altos conocidos hasta entonces, ya que subieron hasta los 28 y 30 maravedíes de media, lo que nos da una ligera idea de la crisis por la que estaba atravesando la ciudad en los últimos años de funcionamiento del pósito, cuando éste poco o nada podía hacer ya para mitigar el hambre de la población tras las sucesivas malas cosechas que se dieron entre 1630 y 1632 , con índices próximos al 70 por ciento. 
CUADRO XVI

EVOLUCIÓN DEL TRIGO Y DINERO DEL PÓSITO ENTRE 1600 Y 1632

\begin{tabular}{|l|c|c|c|c|c|c|}
\hline AÑOS & $\begin{array}{c}\text { CARGO } \\
\text { TRIGO } \\
\text { EN FS }\end{array}$ & $\begin{array}{c}\text { DESCARGO } \\
\text { TRIGO } \\
\text { ENTREGADO }\end{array}$ & $\begin{array}{c}\text { TANTO POR } \\
\text { CIENTO }\end{array}$ & $\begin{array}{c}\text { CARGO } \\
\text { DINERO EN } \\
\text { MRS. }\end{array}$ & $\begin{array}{c}\text { DESCARGO } \\
\text { DINERO EN- } \\
\text { TREGADO }\end{array}$ & $\begin{array}{c}\text { TANTO } \\
\text { POR } \%\end{array}$ \\
\hline $1600 / 01$ & 11.247 & 6.486 & $57,66 \%$ & 4.699 .537 & 3.928 .87 & 183,59 \\
$1601 / 02$ & 12.380 & 3.565 & $28,79 \%$ & 2.894 .929 & 2.329 .519 & 80,47 \\
$1602 / 03$ & 8.815 & 3.729 & $42,30 \%$ & 3.537 .883 & 3.167 .463 & 89,53 \\
$1603 / 04$ & 9.977 & 3.502 & $35,10 \%$ & 5.683 .281 & 5.109 .360 & 89,89 \\
$1604 / 05$ & 13.441 & 11.932 & $88,77 \%$ & 9.341 .690 & 9.072 .940 & 97,12 \\
$1605 / 06$ & 12.563 & 11.564 & $92,04 \%$ & 13.696 .435 & 12.271 .332 & 89,59 \\
$1606 / 07$ & 9.004 & 8.768 & $97,37 \%$ & 15.094 .821 & 11.403 .831 & 75,54 \\
$1607 / 08$ & 7.205 & 6.727 & $93,36 \%$ & 12.304 .282 & 10.748 .125 & 87,35 \\
$1608 / 09$ & 7.178 & 5.786 & $80,60 \%$ & 8.563 .250 & 6.999 .556 & 81,73 \\
$1609 / 10$ & & & & & & \\
$1610 / 11$ & & & & & & \\
$1611 / 12$ & & & & & & \\
$1612 / 13$ & 6.988 & 1.494 & $21,37 \%$ & 3.020 .543 & 1.741 .172 & 57,64 \\
$1613 / 14$ & 7.317 & 4.942 & $67,54 \%$ & 5.989 .659 & 2.347 .542 & 39,18 \\
$1614 / 15$ & & & & & & \\
$1615 / 16$ & 11.639 & 5.956 & $51,17 \%$ & 10.352 .826 & 9.964 .313 & 96,25 \\
$1616 / 17$ & 9.923 & 1.086 & $10,94 \%$ & 4.149 .100 & 2.356 .56 & 56,78 \\
$1617 / 18$ & 6.243 & 4.463 & $71,48 \%$ & 3.591 .434 & 3.646 .954 & 101,53 \\
$1618 / 19$ & 5.927 & 1.619 & $27,31 \%$ & 3.215 .274 & 2.953 .475 & 91,85 \\
$1619 / 20$ & & & & & & \\
$1620 / 21$ & 3.070 & 2.309 & $75,21 \%$ & 3.335 .049 & 3.477 .007 & 104,25 \\
$1621 / 22$ & 2.938 & 96 & $3,26 \%$ & 2.638 .855 & 2.647 .039 & 100,34 \\
$1622 / 23$ & 2.842 & 2.053 & $72,23 \%$ & 2.991 .101 & 2.906 .464 & 97,15 \\
$1623 / 24$ & 2.235 & 1.355 & $60,62 \%$ & 2.885 .354 & 2.820 .500 & 97,74 \\
$1624 / 25$ & 2.032 & 1.123 & $55,26 \%$ & 2.530 .229 & 2.494 .727 & 98,57 \\
$1625 / 26$ & 1.947 & 241 & $12,37 \%$ & 2.607 .013 & 2.572 .935 & 98,65 \\
$1626 / 27$ & 1.711 & 813 & $47,51 \%$ & 2.490 .603 & 2.482 .743 & 99,67 \\
$1627 / 28$ & & & & & & \\
$1628 / 29$ & 1.086 & 187 & $17,21 \%$ & 2.602 .556 & 2.547 .463 & 97,88 \\
$1629 / 30$ & 205 & 205 & $100,00 \%$ & 232.979 & 232.106 & 99,62 \\
$1630 / 31$ & & & & & & \\
$1631 / 32$ & 207 & 207 & $100,00 \%$ & 162.054 & 104.930 & 64,75 \\
\hline
\end{tabular}

Hispania, LXIII/3, núm. 215 (2003) 863-906 


\section{CONCLUSIONES}

El precio del trigo en Guadalajara entre 1547 y 1632 se vio expuesto a los vaivenes característicos de las diferentes crisis que azotaron Castilla a lo largo de todo el periodo, de las que no se libró la propia ciudad alcarreña, así como a otra serie circunstancias de índole diversa como fueron las diferentes aplicaciones de la tasa, los precios de los portes y, especialmente, la actuación de los acaparadores; aunque, sin duda alguna, lo que más determinó la evolución del precio del trigo en Guadalajara fue su pósito. En todo este proceso siempre estuvo presente la iniciativa real, que veía cómo uno de los productos más importantes dentro de la dieta de sus súbditos aumentaba de valor ante la mínima circunstancia negativa que se originase en el mercado. De ahí las numerosas leyes promulgadas tanto por Carlos I como por Felipe II tendentes a eliminar en lo posible las variaciones de precios sin causa justificada y que tuvieron en los acaparadores sus principales destinatarios, al considerarles los artífices de un aumento excesivo en el precio del trigo en años de normalidad cerealística. Leyes que se vieron refrendadas, a su vez, por la imposición de varias tasas que ocasionó no pocos problemas económicos a los propios labradores obligados a vender su trigo a precio inferior al costo del producto.

En este intento por mantener estable el precio del trigo tuvo una incidencia directa el pósito. En unas ocasiones actuó como moderador de los precios del trigo, en especial, en los años en los que la carestía hacía acto de presencia y sacaba todo el grano almacenado en sus graneros para que los ciudadanos pudiesen acceder a un pan cuyo coste se elevaba muy por encima de sus posibilidades económicas; en cambio, en otras, el pósito se convertía en el principal agente provocador, al igual que un rentista o acumulador más, de un alza excesiva en el precio del trigo, al impedir que éste entrase en la ciudad cuando la cosecha había sido abundante, obligando a la población a comprar al precio marcado por el Concejo, más pendiente de no perder demasiado dinero del pósito, por la compra de un grano que previamente había comprado a precios muy altos.

Podemos considerar, que hasta finales del siglo XVI el precio medio del trigo se vio beneficiado por la actuación del pósito, debido a una buena política reflejada tanto desde el punto de vista del almacenamiento de trigo como por el repartimiento que hizo en momentos clave de las diferentes carestías padecidas por la ciudad en esos años, ya que sus vecinos se encontraron con trigo para sembrar o para cocer a un precio inferior al establecido por el propio mercado. Su capacidad de almacenamiento, cantidades comprendidas entre las 12000 y 16000 fanegas por término medio, así como el largo tiempo de almacenaje en los graneros, entre tres y cuatro años, sin que éste enfermase, fue utilizado para mitigar las malas cosechas que se dieron en este período, en especial, durante los años 1598 y 1599.

Sin embargo, a raíz de esta grave carestía, así como por la mala administración que el Concejo hizo del trigo almacenado en sus graneros, utilizando el

Hispania, LXIII/3, núm. 215 (2003) 863-906 
dinero generado por el pósito para dedicarlo a otras cuestiones bien diferentes a las inicialmente establecidas en sus ordenanzas, como el pago del impuesto de millones, provocó que el pósito fuese perdiendo capacidad económica y, por lo tanto, capacidad de respuesta a los problemas que se le avecinaban a Guadalajara, en esos iniciales años del siglo XVII, en los que varias carestías asolaron a su población, como las de 1607,1614 o 1619 que terminaron por minar su fortaleza económica. En esos años el precio del pan alcanzó cotas nunca vistas con anterioridad, hasta 30 maravedíes en 1631, ante la mirada impávida del pósito, sumido en una grave crisis que terminaría con su desaparición en 1632, a pesar de los desesperados esfuerzos de su Concejo por mantener a flote una institución que ellos mismos habían torpedeado. 


\section{APÉNDICE DOCUMENTAL}

CUADRO 1.- EVOLUCIÓN DEL PRECIO MEDIO DE COMPRA DE TRIGO EN MARAVEDÍES; ÍNDICES EFECTIVOS $(1546-1632=100)$ Y MEDIAS MÓVILES.

\begin{tabular}{|c|c|c|c|}
\hline AÑOS & $\begin{array}{l}\text { PRECIOS } \\
\text { MEDIOS }\end{array}$ & $\begin{array}{c}\text { ÍNDICES EFECTIVOS } \\
(1546-1632: 100)\end{array}$ & $\begin{array}{l}\text { MEdIAS MÓVILES } \\
\text { (5 AÑOS) }\end{array}$ \\
\hline 1546 & 362 & 74 & \\
\hline 1547 & 444 & 91 & \\
\hline 1548 & 425 & 87 & 70 \\
\hline 1549 & 318 & 65 & 59 \\
\hline 1550 & $\ldots$ & $\ldots$ & $\ldots$ \\
\hline 1551 & 153 & 31 & 52 \\
\hline 1552 & $\ldots$ & $\ldots$ & $\ldots$ \\
\hline 1553 & $\ldots$ & $\ldots$ & $\ldots$ \\
\hline 1554 & 98 & 20 & 52 \\
\hline 1555 & 280 & 57 & 39 \\
\hline 1556 & 428 & 88 & 68 \\
\hline 1557 & 509 & 105 & 79 \\
\hline 1558 & 353 & 72 & 81 \\
\hline 1559 & 362 & 74 & 76 \\
\hline 1560 & 310 & 64 & 67 \\
\hline 1561 & 310 & 64 & 66 \\
\hline 1562 & 310 & 64 & 64 \\
\hline 1563 & 310 & 64 & 63 \\
\hline 1564 & 310 & 64 & 62 \\
\hline 1565 & 287 & 59 & 62 \\
\hline 1566 & 300 & 62 & 62 \\
\hline 1567 & 310 & 64 & 62 \\
\hline 1568 & 310 & 64 & 63 \\
\hline 1569 & 310 & 64 & 65 \\
\hline 1570 & 310 & 64 & 67 \\
\hline 1571 & 342 & 70 & 66 \\
\hline 1572 & 374 & 72 & 67 \\
\hline 1573 & 268 & 55 & 68 \\
\hline 1574 & 340 & 7.0 & 70 \\
\hline 1575 & 344 & 71 & 73 \\
\hline 1576 & 374 & 77 & 92 \\
\hline 1577 & 442 & 91 & 98 \\
\hline 1578 & 748 & 154 & 98 \\
\hline 1579 & 467 & 96 & 99 \\
\hline 1580 & 364 & 75 & 100 \\
\hline 1581 & 374 & 77 & 91 \\
\hline 1582 & 476 & 98 & 100 \\
\hline
\end{tabular}

Hispania, LXIII/3, núm. 215 (2003) 863-906 


\begin{tabular}{|c|c|c|c|}
\hline AÑos & $\begin{array}{l}\text { PRECIOS } \\
\text { MEDIOS }\end{array}$ & $\begin{array}{l}\text { ÍNDICES EFECTIVOS } \\
(1546-1632: 100)\end{array}$ & $\begin{array}{l}\text { MEDIAS MÓVILES } \\
\text { (5 AÑ̃S) }\end{array}$ \\
\hline 1583 & 544 & 112 & 94 \\
\hline 1584 & 668 & 138 & 92 \\
\hline 1585 & 221 & 45 & 96 \\
\hline 1586 & 340 & 70 & 100 \\
\hline 1587 & & $\ldots$ & \\
\hline 1588 & 568 & 117 & 98 \\
\hline 1589 & 641 & 132 & 116 \\
\hline 1590 & 614 & 126 & 126 \\
\hline 1591 & 658 & 135 & 134 \\
\hline 1592 & 572 & 118 & 137 \\
\hline 1593 & 765 & 158 & 160 \\
\hline 1594 & 731 & 151 & 151 \\
\hline 1595 & 1.167 & 241 & 147 \\
\hline 1596 & 433 & 89 & 135 \\
\hline 1597 & 467 & 96 & 132 \\
\hline 1598 & 476 & 98 & 119 \\
\hline 1599 & 677 & 139 & 116 \\
\hline 1600 & 850 & 175 & 116 \\
\hline 1601 & 340 & 70 & 116 \\
\hline 1602 & 470 & 98 & 106 \\
\hline 1603 & 476 & 98 & 98 \\
\hline 1604 & 442 & 91 & 112 \\
\hline 1605 & 646 & 133 & 125 \\
\hline 1606 & 688 & 142 & 133 \\
\hline 1607 & 794 & 164 & 139 \\
\hline 1608 & 671 & 138 & 150 \\
\hline 1609 & 578 & 119 & 134 \\
\hline 1610 & 901 & 186 & 123 \\
\hline 1611 & 306 & 63 & 110 \\
\hline 1612 & 531 & 109 & 122 \\
\hline 1613 & 391 & 80 & 114 \\
\hline 1614 & 825 & 170 & 127 \\
\hline 1615 & 722 & 149 & 130 \\
\hline 1616 & 614 & 126 & 139 \\
\hline 1617 & 612 & 126 & 126 \\
\hline 1618 & 612 & 126 & 120 \\
\hline 1619 & $\ldots$ & $\ldots$ & $\ldots$ \\
\hline 1620 & 510 & 105 & 118 \\
\hline 1621 & 561 & 115 & 115 \\
\hline 1622 & 583 & 120 & 113 \\
\hline 1623 & 527 & 108 & 115 \\
\hline 1624 & 578 & 119 & 113 \\
\hline 1625 & 544 & 112 & 114 \\
\hline 1626 & 510 & 105 & 115 \\
\hline
\end{tabular}

Hispania, LXIII/3, núm. 215 (2003) 863-906 


\begin{tabular}{|l|c|c|c|}
\hline AÑOS & $\begin{array}{c}\text { PRECIOS } \\
\text { MEDIOS }\end{array}$ & $\begin{array}{c}\text { ÍNDICES EFECTIVOS } \\
(1546-1632: 100)\end{array}$ & $\begin{array}{c}\text { MEDIAS MÓVILES } \\
\text { (5 AÑOS) }\end{array}$ \\
\hline 1627 & 612 & 126 & 125 \\
1628 & 544 & 112 & 129 \\
1629 & 816 & 168 & 152 \\
1630 & 663 & 136 & \\
1631 & 1.054 & 217 & \\
1632 & $\ldots$ & $\ldots$ & \\
\hline
\end{tabular}

CUADRO 2.- EVOLUCIÓN DEL PRECIO MEDIO DE VENTA DE TRIGO EN MARAVEDÍES; ÍNDICES EFECTIVOS (1582-1632=100) Y MEDIAS MÓVILES.

\begin{tabular}{|c|c|c|c|}
\hline AÑOS & $\begin{array}{l}\text { PRECIOS } \\
\text { MEDIOS }\end{array}$ & $\begin{array}{l}\text { ÍNDICES EFECTIVOS } \\
(1546-1632: 100)\end{array}$ & $\begin{array}{l}\text { MEDIAS MÓVILES } \\
\text { (5 AÑOS) }\end{array}$ \\
\hline 1582 & 421 & 70 & \\
\hline 1583 & 555 & 93 & \\
\hline 1584 & 652 & 109 & 86 \\
\hline 1585 & 544 & 91 & 82 \\
\hline 1586 & 417 & 69 & 79 \\
\hline 1587 & 289 & 48 & 74 \\
\hline 1588 & $\ldots$ & & $\ldots$ \\
\hline 1589 & 476 & 79 & 77 \\
\hline 1590 & 486 & 81 & 80 \\
\hline 1591 & 632 & 106 & 91 \\
\hline 1592 & 528 & 88 & 96 \\
\hline 1593 & 600 & 100 & 102 \\
\hline 1594 & 617 & 103 & 96 \\
\hline 1595 & 680 & 114 & 98 \\
\hline 1596 & $\ldots$ & $\ldots$ & $\ldots$ \\
\hline 1597 & 457 & 76 & 99 \\
\hline 1598 & 573 & 96 & 103 \\
\hline 1599 & 646 & 108 & 96 \\
\hline 1600 & 737 & 123 & 92 \\
\hline 1601 & 451 & 75 & 86 \\
\hline 1602 & 340 & 57 & 88 \\
\hline 1603 & $\ldots$ & $\ldots$ & $\ldots$ \\
\hline 1604 & 408 & 68 & 94 \\
\hline 1605 & 702 & 117 & 109 \\
\hline 1606 & 902 & 151 & 123 \\
\hline 1607 & 918 & 154 & 134 \\
\hline 1608 & 755 & 126 & 125 \\
\hline 1609 & 734 & 123 & 114 \\
\hline 1610 & $\ldots$ & $\ldots$ & $\ldots$ \\
\hline 1611 & . $\quad \ldots$ & $\ldots$ & $\ldots$ \\
\hline 1612 & 414 & 73 & 104 \\
\hline
\end{tabular}

Hispania, LXIII/3, núm. 215 (2003) 863-906 


\begin{tabular}{|l|c|c|c|}
\hline AÑOS & $\begin{array}{c}\text { PRECIOS } \\
\text { MEDIOS }\end{array}$ & $\begin{array}{c}\text { ÍNDICES EFECTIVOS } \\
(1546-1632: 100)\end{array}$ & $\begin{array}{c}\text { MEDIAS MÓVILES } \\
\text { (5 AÑOS) }\end{array}$ \\
\hline 1613 & 564 & 94 & 109 \\
1614 & 626 & 105 & 109 \\
1615 & 893 & 149 & 117 \\
1616 & 730 & 122 & 117 \\
1617 & 681 & 114 & 117 \\
1618 & 578 & 96 & 105 \\
1619 & 612 & 102 & 100 \\
1620 & 540 & 90 & 98 \\
1621 & 591 & 99 & 97 \\
1622 & $\ldots$ & $\ldots$ & $\ldots$ \\
1623 & 627 & 105 & 91 \\
1624 & 544 & 91 & 91 \\
1625 & 482 & 80 & 91 \\
1626 & 746 & 79 & 105 \\
1627 & 612 & 102 & 108 \\
1628 & 612 & 102 & \\
1629 & $\ldots$ & $\ldots$ & \\
1630 & 960 & 161 & \\
1631 & $\ldots$ & 96 & \\
1632 & 576 & & \\
\hline
\end{tabular}

CUADRO 3.- EVOLUCIÓN DEL PRECIO MEDIO DE COMPRA DE TRIGO, 1546 Y 1632. DESVIACIONES CÍCLICAS.

\begin{tabular}{|l|c|c|c|c|}
\hline AÑOS & $\begin{array}{c}\text { ÍNDICES } \\
\text { EFECTIVOS } \\
(1546-1632: 100)\end{array}$ & $\begin{array}{c}\text { MEDIAS } \\
\text { MÓVILES } \\
\text { (5 AÑOS) }\end{array}$ & $\begin{array}{c}\text { DESVIACIONES } \\
\text { CÍCLICAS } \\
\text { ABSOLUTAS }\end{array}$ & $\begin{array}{c}\text { DESVIACIONES } \\
\text { CÍCLICAS } \\
\text { RELATIVAS }\end{array}$ \\
\hline 1546 & 74 & & & \\
1547 & 91 & & & \\
1548 & 87 & 69 & 18 & $26,08 \%$ \\
1549 & 65 & 59 & 6 & $10,16 \%$ \\
1550 &.. &. &.. & $\ldots \ldots$ \\
1551 & 31 & 52 & -19 & $-36,50 \%$ \\
1552 &.. &.. &.. & $\ldots \ldots .$. \\
1553 &.. & 52 & -32 & $\ldots 1,53 \%$ \\
1554 & 20 & 60 & -3 & $-5 \%$ \\
1555 & 57 & 68 & -20 & $-29,41 \%$ \\
1556 & 88 & 79 & 26 & $32,91 \%$ \\
1557 & 105 & 81 & -9 & $-11,11 \%$ \\
1558 & 72 & 76 & -2 & $-2,63 \%$ \\
1559 & 74 & 67 & -3 & $-4,47 \%$ \\
1560 & 64 & & &
\end{tabular}

Hispania, LXIII/3, núm. 215 (2003) 863-906 


\begin{tabular}{|l|c|c|c|c|}
\hline AÑOS & $\begin{array}{c}\text { Í́NDICES } \\
\text { EFECTIVOS } \\
(1546-1632: 100)\end{array}$ & $\begin{array}{c}\text { MEDIAS } \\
\text { MÓVILES } \\
\text { (5 AÑOS) }\end{array}$ & $\begin{array}{c}\text { DESVIACIONES } \\
\text { CÍCICAS } \\
\text { ABSOLUTAS }\end{array}$ & $\begin{array}{c}\text { DESVIACIONES } \\
\text { CÍCICAS } \\
\text { RELATIVAS }\end{array}$ \\
\hline 1561 & 64 & 66 & -2 & $-3,03 \%$ \\
1562 & 64 & 64 & 0 & $0 \%$ \\
1563 & 64 & 63 & 1 & $1,58 \%$ \\
1564 & 64 & 62 & 2 & $3,12 \%$ \\
1565 & 59 & 62 & -3 & $-4,83 \%$ \\
1566 & 62 & 62 & 0 & $0 \%$ \\
1567 & 64 & 62 & 2 & $3,12 \%$ \\
1568 & 64 & 63 & 1 & $1,58 \%$ \\
1569 & 64 & 65 & -1 & $-1,53 \%$ \\
1570 & 64 & 67 & -3 & $-4,47 \%$ \\
1571 & 70 & 66 & 4 & $6,06 \%$ \\
1572 & 72 & 67 & 5 & $7,46 \%$ \\
1573 & 55 & 68 & -13 & $-19,11 \%$ \\
1574 & 70 & 70 & 0 & $0 \%$ \\
1575 & 71 & 73 & -2 & $-2,73 \%$ \\
1576 & 77 & 92 & -15 & $-16,30 \%$ \\
1577 & 91 & 98 & -7 & $-7,14 \%$ \\
1578 & 154 & 98 & 56 & $57,14 \%$ \\
1579 & 96 & 99 & -3 & $-3,03 \%$ \\
1580 & 75 & 100 & -25 & $25 \%$ \\
1581 & 77 & 91 & -14 & $-15,38 \%$ \\
1582 & 98 & 100 & -2 & $-2 \%$ \\
1583 & 112 & 94 & 18 & $19,14 \%$ \\
1584 & 138 & 92 & 46 & $50 \%$ \\
1585 & 45 & 96 & -51 & $-53,12 \%$ \\
1586 & 70 & 100 & -30 & $-30 \%$ \\
1587 &.- & -3 & & \\
1588 & 117 & 98 & 19 & $19,38 \%$ \\
1589 & 132 & 116 & 16 & $13,79 \%$ \\
1590 & 126 & 126 & 0 & $0 \%$ \\
1591 & 135 & 134 & 1 & $0,74 \%$ \\
1592 & 118 & 137 & -19 & $-13,86 \%$ \\
1593 & 158 & 160 & -2 & $-1,25 \%$ \\
1594 & 151 & 151 & 0 & $0 \%$ \\
1595 & 241 & 147 & 94 & $63,94 \%$ \\
1596 & 89 & 135 & -46 & $-34,07 \%$ \\
1597 & 96 & 132 & -36 & $-27,27 \%$ \\
1598 & 98 & 119 & -21 & $-17,64 \%$ \\
1599 & 139 & 116 & 23 & $19,82 \%$ \\
1600 & 175 & 116 & 59 & $50,86 \%$ \\
1601 & 70 & 116 & -46 & $-39,65 \%$ \\
1602 & 98 & 106 & -8 & $-7,54 \%$ \\
1603 & 98 & 98 & 0 & $0 \%$ \\
& & & &
\end{tabular}

Hispania, LXIII/3, núm. 215 (2003) 863-906 


\begin{tabular}{|c|c|c|c|c|}
\hline AÑos & $\begin{array}{c}\text { ÍNDICES } \\
\text { EFECTIVOS } \\
(1546-1632: 100)\end{array}$ & $\begin{array}{l}\text { MEDIAS } \\
\text { MÓVILES } \\
\text { (5 AÑOS) }\end{array}$ & $\begin{array}{l}\text { DESVIACIONES } \\
\text { CÍCLICAS } \\
\text { ABSOLUTAS }\end{array}$ & $\begin{array}{c}\text { DESVIACIONES } \\
\text { CÍCLICAS } \\
\text { RELATIVAS }\end{array}$ \\
\hline 1604 & 91 & 112 & -21 & $-18,75 \%$ \\
\hline 1605 & 133 & 125 & 8 & $6,40 \%$ \\
\hline 1606 & 142 & 133 & 9 & $6,76 \%$ \\
\hline 1607 & 164 & 139 & 25 & $17,98 \%$ \\
\hline 1608 & 138 & 150 & -12 & $-8 \%$ \\
\hline 1609 & 119 & 134 & -15 & $11,19 \%$ \\
\hline 1610 & 186 & 123 & 63 & $51,21 \%$ \\
\hline 1611 & 63 & 110 & -47 & $-42,72 \%$ \\
\hline 1612 & 109 & 122 & -13 & $-10,65 \%$ \\
\hline 1613 & 80 & 114 & -34 & $-29,82 \%$ \\
\hline 1614 & 170 & 127 & 43 & $33,85 \%$ \\
\hline 1615 & 149 & 130 & 19 & $14,61 \%$ \\
\hline 1616 & 126 & 139 & -13 & $-9,35 \%$ \\
\hline 1617 & 126 & 126 & 0 & $0 \%$ \\
\hline 1618 & 126 & 120 & 6 & $5 \%$ \\
\hline 1619 & .. & ... & .. & $\ldots$ \\
\hline 1620 & 105 & 118 & -13 & $-11,01 \%$ \\
\hline 1621 & 115 & 115 & 0 & $0 \%$ \\
\hline 1622 & 120 & 113 & 7 & $6,19 \%$ \\
\hline 1623 & 108 & 115 & -7 & $-6,08 \%$ \\
\hline 1624 & 119 & 113 & 6 & $5,30 \%$ \\
\hline 1625 & 112 & 114 & -2 & $-1,75 \%$ \\
\hline 1626 & 105 & 115 & -10 & $-8,69 \%$ \\
\hline 1627 & 126 & 125 & 1 & $0,8 \%$ \\
\hline 1628 & 112 & 129 & -17 & $-13,17 \%$ \\
\hline 1629 & 168 & 152 & 16 & $10,52 \%$ \\
\hline 1630 & 136 & & & \\
\hline 1631 & 217 & & & \\
\hline
\end{tabular}

CUADRO 4.- EVOLUCIÓN DEL PRECIO MEDIO DE VENTA DE TRIGO, 1582 Y 1632. DESVIACIONES CÍCLICAS.

\begin{tabular}{|l|c|c|c|c|}
\hline AÑOS & $\begin{array}{c}\text { ÍNDICES } \\
\text { EFECTIVOS } \\
(1546-1632: 100)\end{array}$ & $\begin{array}{c}\text { MEDIAS } \\
\text { MÓVILES } \\
\text { (5 AÑOS) }\end{array}$ & $\begin{array}{c}\text { DESVIACIONES } \\
\text { CÍCLICAS } \\
\text { ABSOLUTAS }\end{array}$ & $\begin{array}{c}\text { DESVIACIONES } \\
\text { CÍCLICAS } \\
\text { RELATIVAS }\end{array}$ \\
\hline 1582 & 70 & & & \\
1583 & 93 & & 23 & $26,74 \%$ \\
1584 & 109 & 86 & 9 & $10,97 \%$ \\
1585 & 91 & 82 & -10 & $-12,65 \%$ \\
1586 & 69 & 79 & -26 & $-35,13 \%$ \\
1587 & 48 & 74 & &
\end{tabular}

Hispania, LXIII/3, núm. 215 (2003) 863-906 
ÁNGEL MEJÍA ASENSIO

\begin{tabular}{|c|c|c|c|c|}
\hline AÑos & $\begin{array}{c}\text { ÍNDICES } \\
\text { EFECTIVOS } \\
(1546-1632: 100)\end{array}$ & $\begin{array}{l}\text { MEDIAS } \\
\text { MÓVILES } \\
\text { (5 ANNOS) }\end{array}$ & $\begin{array}{l}\text { DESVIACIONES } \\
\text { CÍCLICAS } \\
\text { ABSOLUTAS }\end{array}$ & $\begin{array}{l}\text { DESVIACIONES } \\
\text { CíCLICAS } \\
\text { RELATIVAS }\end{array}$ \\
\hline 1588 & & & & \\
\hline 1589 & 79 & 77 & $\ddot{2}$ & $2,59 \%$ \\
\hline 1590 & 81 & 80 & 1 & $1,25 \%$ \\
\hline 1591 & 106 & 91 & 15 & $16,48 \%$ \\
\hline 1592 & 88 & 96 & -8 & $-8,33 \%$ \\
\hline 1593 & 100 & 102 & -2 & $-1,96 \%$ \\
\hline 1594 & 103 & 96 & 7 & $7,29 \%$ \\
\hline 1595 & 114 & 98 & 16 & $16,32 \%$ \\
\hline 1596 & & & & \\
\hline 1597 & 76 & 99 & 23 & $23,23 \%$ \\
\hline 1598 & 96 & 103 & 7 & $6,79 \%$ \\
\hline 1599 & 108 & 96 & 12 & $12,5 \%$ \\
\hline 1600 & 123 & 92 & 31 & $33,69 \%$ \\
\hline 1601 & 75 & 86 & -11 & $-12,79 \%$ \\
\hline 1602 & 57 & 88 & -31 & $-35,22 \%$ \\
\hline 1603 & & & & \\
\hline 1604 & 68 & 94 & -26 & $-27,65 \%$ \\
\hline 1605 & 117 & 109 & 8 & $7,33 \%$ \\
\hline 1606 & 151 & 123 & 28 & $22,76 \%$ \\
\hline 1607 & 154 & 134 & 20 & $14,92 \%$ \\
\hline 1608 & 126 & 125 & 1 & $0,8 \%$ \\
\hline 1609 & 123 & 114 & 9 & $7,89 \%$ \\
\hline 1610 & $\ldots$ & $\ldots$ & $\ldots$ & ..... \\
\hline 1611 & & & $\ldots$ & \\
\hline 1612 & 73 & 104 & -29 & $-27,88 \%$ \\
\hline 1613 & 94 & 109 & -15 & $-13,76 \%$ \\
\hline 1614 & 105 & 109 & -4 & $-3,66 \%$ \\
\hline 1615 & 149 & 117 & 32 & $27,35 \%$ \\
\hline 1616 & 122 & 117 & 5 & $4,27 \%$ \\
\hline 1617 & 114 & 117 & -3 & $-2,56 \%$ \\
\hline 1618 & 96 & 105 & -9 & $-8,57 \%$ \\
\hline 1619 & 102 & 100 & 2 & $2 \%$ \\
\hline 1620 & 90 & 98 & -8 & $-8,16 \%$ \\
\hline 1621 & 99 & 97 & 2 & $2,06 \%$ \\
\hline 1622 & & & & \\
\hline 1623 & 105 & 93 & 12 & $12,90 \%$ \\
\hline 1624 & 91 & 91 & 0 & $0 \%$ \\
\hline 1625 & 80 & 91 & -11 & $-12,08 \%$ \\
\hline 1626 & 79 & 91 & -12 & $-13,18 \%$ \\
\hline 1627 & 102 & 105 & -3 & $-2,85 \%$ \\
\hline 1628 & 102 & 108 & -6 & $-5,55 \%$ \\
\hline 1629 & & $\cdots$ & & \\
\hline 1630 & 161 & & & \\
\hline 1631 & $\ldots$ & & & \\
\hline 1632 & 96 & & & \\
\hline
\end{tabular}

Hispania, LXIII/3, núm. 215 (2003) 863-906 